Ocean Sci. Discuss., https://doi.org/10.5194/os-2018-142

Manuscript under review for journal Ocean Sci.

\title{
Remote sensing of upwelling off Australia's north-east coast
}

\author{
Mochamad Furqon Azis Ismail ${ }^{1,4}$, Joachim Ribbe ${ }^{1}$, Johannes Karstensen ${ }^{2}$, Vincent Rossi ${ }^{3}$ \\ ${ }^{1}$ Faculty of Health Engineering and Sciences, School of Agricultural, Computational and Environmental Sciences, University \\ of Southern Queensland, Toowoomba 4350, Queensland, Australia. \\ $5 \quad{ }^{2}$ GEOMAR, Helmholtz Centre for Ocean Research Kiel, 24105 Kiel, Germany. \\ ${ }^{3}$ Mediterranean Institute of Oceanography (MIO, UM 110, UMR 7294), CNRS, Aix-Marseille University, University of \\ Toulon, IRD, 13288 Marseille, France. \\ ${ }^{4}$ Research Centre for Oceanography - Indonesian Institute of Sciences, Jakarta 14430, Indonesia. \\ Correspondence to: Mochamad Furqon Azis Ismail (Furqon.AzisIsmail@usq.edu.au)
}

10 Abstract. Cross-shelf processes drive the exchange of water between the continental shelf and western boundary currents, leading to the import and export of heat, freshwater, sediments, nutrients, plankton, fish larvae, and other properties. Upwelling is an important process which modulates those exchanges. It regulates primary productivity, which in turn promotes higher trophic levels and fisheries. In this paper, we investigate upwelling events in the East Australian Current (EAC) intensification zone off Southeast Queensland through the analysis of remotely-sensed Chlorophyll-a (Chl-a) and Sea Surface Temperature

15 (SST) as well as wind and ocean reanalysis products. A particular focus is on identifying the likely mechanisms that drive upwelling events during the austral autumn to winter which are evident from cold SST and enhanced Chl-a concentrations. Four complementary Upwelling Indices (UIs) are derived. Chl-a (UI Chla $_{\text {) }}$ and SST (UISST) based indices characterize the oceanic response to upwelling, while indices based on wind $\left(\mathrm{UI}_{\mathrm{w}}\right)$ and current $\left(\mathrm{UI}_{\mathrm{c}}\right)$ data capture the forcing of upwelling. The spatial and temporal variability of all UIs is examined over the continental shelf. It reveals distinct seasonal patterns. For the

20 northern region, UIs identify the well-known Southeast Fraser Island Upwelling System. It prevails during the austral spring to early summer and is driven by current- and upwelling favourable wind. In contrast, upwelling is enhanced over the southern shelf during austral autumn to winter. About $70 \%$ of all $\mathrm{UI}_{\mathrm{SST}}$ and $\mathrm{UI}_{\mathrm{Chla}}$ identified upwelling events occur during this period. A case study is presented that provides observational evidence for the existence of a shelf-break upwelling. Simultaneous downwelling favourable wind stress and upwelling favourable current-driven bottom stress establish a flow convergence in

25 the bottom boundary layer (BBL). These convergent BBL flows force upwelling of cold and nutrient-rich slope waters as evident from negative SST anomaly and enhanced Chl-a in austral autumn to winter. It is evident from these results that the shelf region is characterised by two distinct seasonally reoccurring upwelling regimes.

\section{Introduction}

Cross-shelf processes play an important role in the exchange and mixing of coastal waters over the continental shelf and the

30 offshore waters of adjacent boundary currents. It leads to the export and import of properties such as sediments, nutrients, carbon species and fish larvae (e.g. Brink, 2016). Coastal upwelling is a physical process of particular importance since it is 
Ocean Sci. Discuss., https://doi.org/10.5194/os-2018-142

Manuscript under review for journal Ocean Sci.

Discussion started: 9 January 2019

(c) Author(s) 2019. CC BY 4.0 License.

associated with exchanges both vertically and horizontally. It regulates primary productivity and drives the major fisheries of the Eastern Boundary Upwelling Systems (EBUS) due to persistent winds (e.g. Wang et al., 2015; Kämpf and Chapman, 2016).

5 Upwelling also occurs in Western Boundary Currents (WBCs) but appears to be more sporadic, weaker in intensity and of moderate spatial extent. It results from a combination of current- and wind-driven boundary layer stresses as found for the East Australian Current (EAC, Rossi et al., 2014; Brieva et al., 2015), the Brazil Current (Aguiar et al., 2014), the Agulhas Current (Leber et al., 2017) and the South Atlantic Patagonian shelf (Carranza et al., 2017). Interactions between along-shore wind stress oscillations and shelf-break fronts commonly observed in WBCs can have a significant influence on upwelling through

10 Ekman dynamics (e.g. Siedlecki et al., 2011). Gibbs (2000) and Gibbs et al. (2000) found that concurent actions of downwelling favourable winds and the EAC bottom stress along the shelf-break can establish flow convergence in the Bottom Boundary Layer (BBL) inducing vertical motion and upwelling. This provides a mechanism for the transient but substantial nutrient supply into the euphotic zone resulting in enhanced chlorophyll-a concentrations (e.g. Everett et al., 2014). This study aims to explain upwelling events off the Southeast Queensland coast, Australia (Fig. 1), during the austral autumn to winter and to

15 identify the mechanisms that would explain remotely observed elevated Chlorophyll-a (Chl-a) concentrations and cold surface waters.

The EAC is the WBC of the South Pacific Ocean and forms in the southern Coral Sea at about $15^{\circ} \mathrm{S}$. It intensifies further south into a narrow swift southward flow along the shelf-break extending to about $31^{\circ} \mathrm{S}$, where it separates from the shelf and

20 turns eastward into the Tasman Sea (Ridgway and Dunn, 2003). The EAC exhibits seasonal variability in its transport and hydrographic properties. Its flow is more intense and closer to the coast during summer (Ridgway and Godfrey, 1997). The EAC shelf encroachment drives shoreward cross-shelf transport of cold bottom slope water in the BBL which in turn preconditions upwelling (Schaeffer et al., 2013;Schaeffer et al., 2014;Schaeffer and Roughan, 2015).

25 The preconditioning of upwelling by the EAC and the simultaneous occurrence of upwelling favourable wind stress is known to lift cold and nutrient-rich slope water into the euphotic zone (Rossi et al., 2014). This initiates and sustains Chl-a blooms (e.g. Everett et al., 2014) as well as drives cross-shelf phytoplankton composition and distribution (Armbrecht et al., 2015). Rossi et al. (2014) document the latitudinal difference in the frequency of upwelling events along the east Australian shelf. A maximum of eight days per month of current-driven favourable conditions was found between $25^{\circ}-32^{\circ} \mathrm{S}$. Wind-driven

30 upwelling favourable conditions occurred on about 3-6 days per month with a maximum observed during austral spring and summer (Rossi et al. 2014).

Most studies of upwelling along the southeast coast of Australia focus on the EAC separation zone located to the south of about $31^{\circ}$ S (e.g. Gibbs et al., 1998;Gibbs et al., 2000;Roughan and Middleton, 2002, 2004;Schaeffer et al., 2013;Wood et al., 
Ocean Sci. Discuss., https://doi.org/10.5194/os-2018-142

Manuscript under review for journal Ocean Sci.

Discussion started: 9 January 2019

(c) Author(s) 2019. CC BY 4.0 License.

2016). Previous studies of elevated Chl-a, nutrients and Sea Surface Temperature anomalies (SSTa) and associated coastal upwelling off southeast Queensland by Middleton et al. (1994) and Brieva et al. (2015) focus on the austral spring to summer. In this paper, we investigate the causes of remotely-sensed seasonally reoccurring mid-shelf elevated Chl-a and negative SSTa during austral autumn to winter. Furthermore, Brieva et al.'s (2015) results are based only on the analysis of remotely sensed

5 Chl-a. Negative SSTa, indicative of upwelled cooler subsurface waters, was not investigated further and this paper expands on that analysis. Rossi et al. (2014) provided a broader view of sporadic upwelling along the eastern Australian shelf without focussing in detail on the shelf of southeast Queensland. In addition, complex bathymetry, convoluted coastline, and a series of islands along $25^{\circ}-27^{\circ} \mathrm{S}$ advocate for the need to re-evaluate and refine Rossi et al.'s (2014) findings in this region.

10 In this study, we apply a combination of ocean and climate datasets to investigate the causes of upwelling and to understand the spatial and temporal evolution of Chl-a and SSTa in a less well studied region of the EAC. Wind- and EAC boundary layer stresses are the two main physical processes that drive upwelling along the coastal shelf of Australia (e.g. Schaeffer et al. 2013, Rossi et al. 2014, Brieva et al. 2015). Therefore, we utilize wind and current induced BBL stresses to compute upwelling indices and to quantify the characteristics of upwelling events based on these two drivers. Due to the temporal resolution of

15 the data used in this study, we focus on long-lived ( $\geq 8$ days) upwelling events. We analyse and compare upwelling indices derived from satellite remotely-sensed Chl-a, SST, scatterometer wind, and ocean reanalysis to describe upwelling events in southeast Queensland shelf waters. The findings contribute to an improved understanding of the physical processes that maintain the prominent ecological and marine biodiversity which characterises the shelf waters of the region (e.g. Ward et al., 2003; Neira and Keane, 2008; Young et al., 2011;Dambacher et al., 2012).

This paper is organized as follows: Section 2 describes the geographical and physical characteristics of the study site, the data used and methods applied to compute four upwelling indices from Chl-a, SST, wind and current data. Our results are presented in Section 3, where the spatial features of the seasonally reoccurring elevated Chl-a and negative SSTa distributions as well as their temporal variability are discussed in Sections 3.1 and 3.2, respectively. Section 3.3 examines a census of upwelling events using the four upwelling indices. This is followed by a characterisation of the upwelling mechanisms from exploring the temporal climatological variation of spatially averaged Chl-a, SSTa, Ekman transport and bottom layer stress in Section 3.4. Discussion and conclusions are presented in Section 4 with a particular focus on a case study that underpins the conceptual model of shelf-break front promoted upwelling off southeast Queensland.

\section{Study Site, Data and Methodology}

\section{$30 \quad 2.1$ Study Site}

We refer to the study region as the Southeast Queensland Marine Coastal Zone (SEQMCZ). It is defined as the coastal shelf ocean between $25^{\circ}-27^{\circ} \mathrm{S}$ and it extends eastward to the $200 \mathrm{~m}$ isobath (Fig. 1). The on-shelf circulation is characterised by the 
Ocean Sci. Discuss., https://doi.org/10.5194/os-2018-142

Manuscript under review for journal Ocean Sci.

Discussion started: 9 January 2019

(c) Author(s) 2019. CC BY 4.0 License.

seasonally appearing and wind-driven Fraser Gyre (Azis Ismail et al., 2017), which influences cross-shelf exchanges. It possibly facilitates the offshore transport of cold shelf water, Chl-a and larval fish (Ward et al., 2003; Keane and Neira, 2008; Ribbe et al., 2018). The climate of the region is subtropical with maximum rainfall during the austral spring and summer (e.g. Ribbe, 2014). Here, the EAC approaches the shelf-break and intensifies with the strongest flow occurring during austral spring

5 and summer and the region is often referred to as the intensification zone of the EAC (Ridgway and Godfrey, 1997).

High Chl-a concentrations and cold surface water are frequently observed south of Fraser Island (Brieva et al., 2015; Wijffels et al., 2018). This is probably due to different mechanisms which include tidal flushing and export of high-nutrient coastal mangrove water (Middleton et al., 1994), a combination of wind- and current-driven upwelling (Rossi et al., 2014) and possibly

10 high river discharge (Brieva et al., 2015). In addition, Brieva et al. (2015) identified two distinct quasi-climatological features of high Chl-a concentrations: the Southeast Fraser Island Upwelling System (Fig. 2a) and the mid-shelf blooms (Fig. 2b). The former has been described in detail and its causes identified by Brieva et al. (2015). Mean Chl-a values of $>0.8 \mathrm{mg} \mathrm{m}^{-3}$ in the northern region of the SEQMCZ during austral spring and summer are well above the background value of $0.2 \mathrm{mg} \mathrm{m}^{-3}$ which characterises Coral Sea water advected within the EAC. The upwelling is driven by the Ekman BBL stress of the EAC

15 encroaching the shelf with the northerly (southward direction) along-shelf wind stress playing a secondary forcing role (Brieva et al., 2015). However, in the southern region of the shelf, Chl-a values are close to the background value during this period and instead enhanced during autumn and winter.

The upwelled nutrient-rich water off Fraser Island generates coastal phytoplankton blooms, which support commercial and 20 recreational fisheries (Ward et al., 2003; Young et al., 2011). It establishes the Southeast Fraser Island Upwelling System (Brieva et al., 2015) as a key ecological region of high primary productivity and an important fishery along Australia's eastern marine region (Dambacher et al., 2012; Evans et al., 2017). The austral autumn to winter mid-shelf bloom identified by Brieva et al. (2015) downstream of Fraser Island has Chl-a values well above the background level of $0.2 \mathrm{mg} \mathrm{m}^{-3}$. The bloom extends far offshore and its eastern limit follows closely the $200 \mathrm{~m}$ isobath (Fig. 2b). The austral spring to summer and autumn to 25 winter difference in the mean Chl-a distribution (Fig. 2c) emphasises the different timing of the Chl-a maxima in the northern $\left(25^{\circ}-26^{\circ} \mathrm{S}\right)$ as opposed to the southern $\left(26^{\circ}-27^{\circ} \mathrm{S}\right)$ region of the SEQMCZ. Brieva et al. (2015) found that the mid-shelf blooms appear to be unrelated to the along-shelf wind or EAC-driven BBL stress, leaving unexplained that local biological hotspot. Furthermore, in-situ wind measurements near $30^{\circ} \mathrm{S}$ by Wood et al. (2016) show that from austral autumn to winter, the wind is dominated by south-easterly direction which is downwelling favourable. Thus, this study aims to investigate and identify 30 the likely drivers of the mid-shelf elevated autumn-winter Chl-a concentrations. 
Ocean Sci. Discuss., https://doi.org/10.5194/os-2018-142

Manuscript under review for journal Ocean Sci.

Discussion started: 9 January 2019

(c) Author(s) 2019. CC BY 4.0 License.

\subsection{Data}

\subsubsection{Chl-a}

MODerate resolution Imaging Spectroradiometer (MODIS) Chl-a estimates with a resolution of about $1 \mathrm{~km}$ were obtained from the Integrated Marine Observing System (IMOS, 2018), which is a National Collaborative Research Infrastructure

5 (NCRIS) supported by the Australian Government. The data is available from the Australian Ocean Data Network (see URL: https://portal.aodn.org.au/). Satellite ocean color derived Chl-a is used as a proxy for phytoplankton biomass to study the biological response to upwelling (Chen et al., 2012). Chl-a distributions are assessed to describe periods of high Chl-a concentrations as well as their spatial distribution (see Fig. 2). The 8-day composite Chl-a data from 2003 to 2016 is used to maximise the temporal resolution and minimise data gaps e.g. due to cloud coverage (Everett et al., 2014). The data was

10 previously utilised by Brieva et al. (2015) who also discussed further data limitations. For example, in near coastal waters, remotely sensed Chl-a is unreliable as bottom reflectance may cause errors. Therefore, the analysis and interpretation presented in this paper is restricted to water deeper than $40 \mathrm{~m}$ (see location of isobath in Fig. 1).

\subsubsection{SST}

Advanced Very High Resolution Radiometer (AVHRR) SST with a spatial resolution of $2 \mathrm{~km}$ is available from IMOS too (see

15 URL: https://portal.aodn.org.au/). The cloud-free data comply with Group for High Resolution Sea Surface Temperature (GHRSST) requirements and further technical details are provided in Griffin et al. (2017). The quality of the IMOS data product is similar to that of the daily SST analysed by Aguiar et al. (2014), Leber et al. (2017) and Jayaram and Kumar (2018) to detect upwelling off Brazil, northern Patagonia Shelf, southeast coast of South Africa and at southwest coast of India, respectively. The 6-day composite IMOS SST data is used in this study to identify long-lived upwelling events in the SEQMCZ

20 during the 2003 to 2016 period. The data were previously used by Brieva et al. (2015) to identify the southeast Fraser Island Upwelling System and its driving forces.

\subsubsection{Scatterometer winds}

An index from wind measurements is developed to characterise upwelling events and quantify associated magnitudes. Wind variability has been found to play a significant role in controlling phytoplankton growth (e.g. Kämpf, 2015). Daily data with a 25 resolution of $25 \mathrm{~km}$ was extracted from two scatterometer satellite products for periods 1999 to 2009 (QuikSCAT) and 2007 to 2016 (ASCAT) from www.remss.com. QuikSCAT wind speed and direction has accuracies similar to ASCAT data (Bentamy et al., 2012).

\subsubsection{Ocean reanalysis}

Daily zonal velocities from BRAN3p5 for the period 2003 to 2012 is used to quantify the EAC-driven upwelling variability.

BRAN3p5 is an ocean modelling data assimilation system (Oke et al., 2008; Oke et al., 2013) which captures realistically the 
Ocean Sci. Discuss., https://doi.org/10.5194/os-2018-142

Manuscript under review for journal Ocean Sci.

Discussion started: 9 January 2019

(c) Author(s) 2019. CC BY 4.0 License.

general circulation off the east coast of Australia and other shelf regions (see e.g. Oke and Griffin, 2011; Wang et al., 2013; Everett et al., 2014; Brieva et al., 2015; Azis Ismail et al., 2017). Azis Ismail et al. (2017) utilized the model data to identify the seasonally appearing Fraser Gyre and found that BRAN3p5 data captured the observed time-varying regional coastal ocean circulation. The BRAN3p5 data is available via OPENDAP at

5 http://dapds00.nci.org.au/thredds/catalog/gb6/BRAN/BRAN3p5/OFAM/catalog.html.

\subsection{Methodologies}

We develop four different upwelling indices to identify and quantify upwelling process. Chl-a and SST derived upwelling indices are used to examine the physical and biological response to upwelling since an increased Chl-a concentration and a negative SSTa is an indicator of upwelling (Section 2.3.1 and 2.3.2). Wind and BBL current stress are the two physical 10 processes previously identified as forcing upwelling along the eastern shelf of Australia (e.g. Rossi et al., 2014; Schaeffer et al., 2013). Here, we utilize wind- and EAC-derived upwelling indices to quantify the mechanisms of upwelling forced by along-shelf wind stress and EAC-driven BBL stress. The methods to obtain the indices are presented in Section 2.3.3 and 2.3.4 respectively.

\subsubsection{Chl-a derived upwelling index (UI Chla $)$}

15 Turbidity of riverine input, re-suspended sediments, and bottom albedo can cause errors and result in overestimated Chl-a data from remote sensing (e.g. Everett et al. 2014). Brieva et al. (2015) found that river runoff into the SEQMCZ appears to be limited to the near-shore inner-shelf zone of $10 \mathrm{~km}$ width coinciding with the approximate location of the $40 \mathrm{~m}$ isobath. Thus, all Chl-a estimates from locations with water depths of less than $40 \mathrm{~m}$ were excluded from analysis (Brieva et al. 2015). The same approach is used in this study.

20

Brieva et al. (2015) applied a Chl-a background value of $0.2 \mathrm{mg} \mathrm{m}^{-3}$ for the SEQMCZ and determined the average length of a Chl-a event or bloom with about 7-8 days. The background value is similar to that found in the Coral Sea (Condie and Dunn, 2006) and to the east off Fraser Island (Dambacher et al., 2012). The same threshold value is used in this study. Data from two zonal cross sections located at $25.5^{\circ} \mathrm{S}$ and $26.5^{\circ} \mathrm{S}$ and extending eastward from the $40 \mathrm{~m}$ to the $200 \mathrm{~m}$ isobath (see Fig. 1) were selected to investigate the occurrence of upwelling favourable events that last at least 8 days.

\subsubsection{SST derived upwelling index (UIssT)}

Following the approach by Leber et al. (2017), we define upwelling favourable condition by examining the occurrence of "cold events". The method identifies the two mean SSTa threshold values of $-0.57^{\circ} \mathrm{C}$ and $-0.48{ }^{\circ} \mathrm{C}$ for the two previously identified representative zonal cross-sections and SSTa with lower values are indicative of upwelling. We also use Aguiar et al.'s (2014)

30 method by substracting the observed SST from its centered 90-day mean to remove seasonality from SST. A spatial filtering 
Ocean Sci. Discuss., https://doi.org/10.5194/os-2018-142

Manuscript under review for journal Ocean Sci.

Discussion started: 9 January 2019

(c) Author(s) 2019. CC BY 4.0 License.

is applied by excluding the near coastal pixels shallower than $40 \mathrm{~m}$ in the SST data to avoid the potential influence from bottom reflectance and turbidity.

\subsubsection{Wind derived upwelling index $\left(\mathrm{UI}_{\mathrm{w}}\right)$}

The Ekman transport estimated from along-shelf wind stress is used to quantify upwelling (e.g. Cropper et al., 2014; Lamont 5 et al., 2017). In this study, the wind upwelling index $\left(\mathrm{UI}_{\mathrm{w}}\right)$ is obtained from the Bakun Index modification (Bakun and Nelson, 1991). It is defined as the fraction of the Ekman transport that is perpendicular to the coast (Alvarez et al., 2011; Rossi et al., 2014). The method used to compute the surface wind stress is described by e.g. Azis Ismail et al. (2017). The $\mathrm{UI}_{\mathrm{w}} \mathrm{was}_{\mathrm{s}}$ computed according to Rossi et al. (2014):

$Q_{x}=\frac{\tau_{y}}{\rho_{w} f}$ and $Q_{y}=-\frac{\tau_{x}}{\rho_{w} f}$

$10 U I_{w}=\sin (\propto) Q_{x}+\cos (\propto) Q_{y}$

where $\mathrm{Q}_{\mathrm{x}}\left(\mathrm{Q}_{\mathrm{y}}\right)$ is the zonal (meridional) Ekman transport $\left(\mathrm{m}^{2} \mathrm{~s}^{-1}\right) ; \tau_{\mathrm{y}}\left(\tau_{\mathrm{x}}\right)$ is the meridional (zonal) wind stress $\left(\mathrm{N} \mathrm{m}^{-2}\right)$; $\rho_{\mathrm{w}}$ is the mean density of sea water $\left(1025 \mathrm{~kg} \mathrm{~m}^{-3}\right)$; $\mathrm{f}$ is the Coriolis parameter $\left(\mathrm{m} \mathrm{s}^{-2}\right)$; $\alpha$ is the angle of the unitary vector pointing northward at the shoreline (degree). Positive and negative values of $\mathrm{UI}_{\mathrm{w}}$ correspond to upwelling and downwelling favourable conditions, respectively.

\section{$15 \quad$ 2.3.4 EAC derived upwelling index (UIc)}

The upwelling index derived from EAC BBL stress $\left(\mathrm{UI}_{\mathrm{c}}\right)$ indicates whether the EAC drives strong onshore Ekman BBL flow along the shelf-break. This potentially uplifts cold and nutrient-rich slope water toward the shelf. Everett et al. (2014) use a threshold value of $\leq-0.08 \mathrm{~N} \mathrm{~m}^{-2}$ with smaller values indicating current driven upwelling favourable conditions. The same threshold value is applied in this study in order to identify current-driven upwelling favourable conditions. The $\tau_{b}\left(\mathrm{~N} \mathrm{~m}^{-2}\right)$ 20 follows from:

$\tau_{b}=\rho_{w} C_{d} v_{b} \sqrt{u_{b}^{2}+v_{b}^{2}}$

where $v_{b}\left(u_{b}\right)$ is the meridional (zonal) velocity $\left(\mathrm{m} \mathrm{s}^{-1}\right)$ at the shelf-break and $\mathrm{C}_{\mathrm{d}}$ is the drag coefficient $(0.0025)$. The meridional velocity component was not rotated to the along-shelf direction which potentially underestimates the along-shelf bottom stress. However, the difference in the bottom stress between the rotated and non-rotated meridional velocity in the SEQMCZ is only about $10 \%$ (Brieva et al. 2015).

\section{Results}

\subsection{Spatial Chl-a and SST features}

The mean monthly Chl-a and SSTa climatologies capture the spatial structure of possible upwelling into the SEQMCZ (Fig. 2 and 3). During austral spring to early summer, increased Chl-a occupies predominantly the region just to the southeast of 
Ocean Sci. Discuss., https://doi.org/10.5194/os-2018-142

Manuscript under review for journal Ocean Sci.

Discussion started: 9 January 2019

(c) Author(s) 2019. CC BY 4.0 License.

Fraser Island with values exceeding $0.8 \mathrm{mg} \cdot \mathrm{m}^{-3}$ (Fig. 2a). This Chl-a bloom characterises the Southeast Fraser Island Upwelling System (Brieva et al. 2015). Chl-a values are below the threshold value of $0.2 \mathrm{mg} \cdot \mathrm{m}^{-3}$ in the southern region of the shelf. In contrast, enhanced Chl-a concentrations are found across all of the shelf from austral autumn to winter and approach the threshold value just to the east of the $200 \mathrm{~m}$ isobath (Fig. 2b). Two distinct larger-scale Chl-a patterns can be identified in Fig.

$52 \mathrm{c}$ which show the difference between the two periods. The negative anomalies in the northern region (blue shading) correspond to the Southeast Fraser Island Upwelling System, whereas positive anomalies in the southern region (red shading) correspond to the mid-shelf blooms. Similar to the Chl-a spatial structure from austral spring and early summer, we find negative SSTa to the southeast of Fraser Island. These anomalies are confined by the $40 \mathrm{~m}$ isobath and the shelf-break and extend southward to about $26.5^{\circ} \mathrm{S}$ (Fig. 3a). In austral autumn and winter, SSTa gradients are weak and SSTa (colder than

10 average) is negative across all of the southern region of the shelf (Fig. 3b).

Negative SSTa values (Fig. 3) coincide with enhanced Chl-a values (Fig. 2c). This is particularly evident during the austral spring and early summer period (Fig 3a, Fig 2c) and is an indication of seasonal upwelling. Positive SSTa values (Fig. 3a) characterise the pathway of warm EAC water that flows along the shelf-break. The presence the EAC appears to serve as an

15 eastern barrier of the continental shelf Chl-a blooms. The climatological views reveal the signatures of two distinct possible upwelling regimes that appear to occur within the SEQMCZ albeit at different seasons.

\subsection{Temporal variability of Chl-a and SST}

A longitude-time Hovmöller diagram of the estimated Chl-a concentrations $\left(\mathrm{mg} \mathrm{m}^{-3}\right)$ is presented in Fig. $4 \mathrm{a}$ for the northern region and in Fig 4b for the southern region of the SEQMCZ. The most noticeable feature is the inter-annual, seasonal and

20 monthly increase of the Chl-a concentrations exceeding the background value of $0.2 \mathrm{mg} \mathrm{m}^{-3}$. The Chl-a blooms extend to about $100 \mathrm{~km}$ offshore and mainly during austral autumn and winter. This is indicative of frequent enhancements of the phytoplankton biomass as measured via Chl-a across the shelf and throughout the year. The eastward extend of the Chl-a bloom provides evidence for the existence of a nutrient enrichment process such as upwelling that controls Chl-a values up to $100 \mathrm{~km}$ offshore. Alternatively, enhanced Chl-a values near the shelf break could also result from the offshore transport and

25 dilution of a bloom that initially originated closer to the coast. During the austral spring to summer, it is evident that the dispersion of Chl-a is restricted to the shelf. The presence of the EAC restricts the eastward extend of the Chl-a blooms.

In the northern region (Fig. 4a), higher Chl-a concentrations typically develop in austral autumn (April and May) and expand fully across the shelf during austral winter to spring each year. In austral summer (December to February), the Chl-a

30 concentrations decrease and is detected offshore to about 40 to $50 \mathrm{~km}$ eastward. The initial development of the Chl-a blooms across the shelf in the southern region each year is quite similar to that of the northern region (Fig. 4b). However, the blooms appear to be shorter in duration and occur primarily during austral autumn and winter. In contrast to the northern region, the Chl-a concentrations in the southern region decrease throughout austral spring to summer (November to February). 
Ocean Sci. Discuss., https://doi.org/10.5194/os-2018-142

Manuscript under review for journal Ocean Sci.

Discussion started: 9 January 2019

(c) Author(s) 2019. CC BY 4.0 License.

An along-shelf Hovmoller diagram of SSTa between $25^{\circ}$ and $27^{\circ} \mathrm{S}$ is shown in Fig. 5. It allows to identify the latitudinal distribution and frequency of cold events that are indicative of upwelling. The analysis is similar to that presented by Aguiar et al. (2014) for the Brazil Current. The shorter period from January 2007 to December 2012 is shown in the lower panel of

5 Fig. 5. It demonstrates the variability of negative SSTa events with different intensities as well as their meridional extend. For example, a negative SSTa of less than $-3^{\circ} \mathrm{C}$ is shown between $25.5^{\circ}$ and $26.5^{\circ} \mathrm{S}$ lasting from about March to April 2012 (see lower panel of Fig 5). Seasonal and monthly negative anomalies, particularly during the austral winter to spring, are clearly identifiable from the time series shown in the lower panel of Fig. 5. Negative anomalies appear from about late July to October and usually disappear in January to February.

\section{$10 \quad 3.3$ Upwelling indices}

\subsubsection{Evidence of upwelling from Chl-a (index UIChla)}

The cumulative number of $\mathrm{UI}_{\mathrm{Chla}}$ detected Chl-a events indicates that concentrations from austral winter to spring are higher than from summer to autumn in both regions (Fig. 6). The period with a higher number of cumulative events is longer in the northern than the southern region. There is an increase in the number of $\mathrm{UI}_{\text {Chla }}$ events $(>10)$ from May to November with a

15 maximum in October in the northern region (Fig. 6a). The number of events decreases in the following months with a minimum in February. In contrast, the period with higher numbers in cumulative $\mathrm{UI}_{\mathrm{Chla}}$ events $(>10)$ is shorter and lasts from May to September in the southern region (Fig. 6b). A maximum of 14 events is found from June to August and in the following months, the number of events decreases to a minimum in January. Thus, the detected pattern in the distribution of events differs distinctly between the northern and southern region. This is also reflected in the total number of events (Table 1). A total of

20145 and 99 events with about $52 \%$ and $70 \%$ in the northern and southern region, respectively, occur during austral autumn and winter. An average about 10 events occurs in the northern and 7 in the southern region per year (Table 1).

\subsubsection{Evidence of upwelling from SSTa (index UISsT)}

The mean monthly distribution of the cumulative number of UIssT identified events resemblances the UI Chla derived pattern (Fig. 7). The number of events increases during the autumn to winter period in both regions with maxima of 9 (Fig. 7 a) and 11

25 (Fig. 7b) in July, yet the overall duration of that period is shorter than that found from $\mathrm{UI}_{\text {Chla }}$ identified events. The total number of cold events in each region is 42 (Table 1). This is about three cold events per year and compares to the five cold events identified by Leber et al. (2017) for the Agulhas current system to the southeast off South Africa. About 52\% and $69 \%$ of these events occur during austral autumn to winter in the northern and southern region, respectively. The autumn to winter period of the southern region is characterised by a higher number of total events than the spring to summer period, while the northern region has about the same total number of events during both periods (Table 1). 
Ocean Sci. Discuss., https://doi.org/10.5194/os-2018-142

Manuscript under review for journal Ocean Sci.

Discussion started: 9 January 2019

(c) Author(s) 2019. CC BY 4.0 License.

\subsubsection{Wind forced upwelling (index $U I_{w}$ )}

Figure 8 shows the cumulative number of $\mathrm{UI}_{\mathrm{w}}$ upwelling and downwelling events identified by applying the methodology presented in Section 2.3.3. The $\mathrm{UI}_{\mathrm{w}}$ (upwelling favourable) events are more frequent from austral spring to summer than from austral autumn to winter in both the northern and southern region (Fig. 8a and 8c). In the northern region, between 7 and 9

5 events occur from September to December (Fig. 8a), while in the southern region, about 10 events per month occur during this period with a maximum number of 16 events in November (Fig. 8c). During the following austral autumn to winter, the number of $\mathrm{UI}_{\mathrm{w}}$ (upwelling favourable) events decreases to less than 2 events in both regions. In contrast, the cumulative number of $\mathrm{UI}_{\mathrm{w}}$ detected downwelling favourable events increases from a minimum period between September and November to a period characterised by a maximum number of events that lasts until about July (Fig 8b and 8d).

10

The cumulative number of $\mathrm{UI}_{\mathrm{w}}$ detected events indicating downwelling favourable conditions is consistently much larger than the number of $\mathrm{UI}_{\mathrm{w}}$ detected events indicating upwelling favourable conditions. From January to July more than 10 events are found for each month (Fig. $8 \mathrm{~b}$ and 8d). A maximum number of 16 events is observed during May and June for the northern and in March for the southern region of the shelf. Overall, the total number of $\mathrm{UI}_{\mathrm{w}}$ (upwelling favourable) events for the

15 northern and southern region is 43 and 57 events, respectively (see Table 1). In contrast, the total number of $\mathrm{UI}_{\mathrm{w}}$ downwelling favourable events is 132 in the northern region and 129 in the southern region. This is about two to three times the number of $\mathrm{UI}_{\mathrm{w}}$ upwelling favourable events. Despite the wind direction being mostly southerly and therefore downwelling favourable during austral autumn to winter, we still find positive $\mathrm{UI}_{\mathrm{w}}$ (upwelling favourable) events which account for $9 \%$ and $7 \%$ of the total in northern and southern region. However, negative $\mathrm{UI}_{\mathrm{w}}$ (downwelling favourable) events make up $62 \%$ and $65 \%$ of

20 the total in the northern and southern region. On average, about 3 to 4 upwelling events (positive $\mathrm{UI}_{\mathrm{w}}$ ) occur each year, whereas downwelling events (negative $\mathrm{UI}_{\mathrm{w}}$ ) occur about 9 times per year (Table 1).

\subsubsection{Current forced upwelling (index $\mathrm{UI}_{c}$ )}

The cumulative number of current derived upwelling favourable events $\left(\mathrm{UI}_{\mathrm{c}}\right)$ is shown in Fig. 9 for the period 2003-2012. Upwelling favourable events occur every month throughout the year in both regions. The events seem to occur more frequent in the northern than in the southern region. The two maxima of 8 and 10 upwelling favourable events occur in May and September for the northern region, while in the southern region 10 and 7 upwelling events appear in May and April/October. In total, there are 79 (64) upwelling favourable events and about $44 \%$ (48\%) of them take place in austral autumn to winter in the northern (southern) region of the shelf (see Table 1). On average, there are 5 to 6 current-driven upwelling favourable events each year over the period 2003-2012. 
Ocean Sci. Discuss., https://doi.org/10.5194/os-2018-142

Manuscript under review for journal Ocean Sci.

Discussion started: 9 January 2019

(c) Author(s) 2019. CC BY 4.0 License.

\subsection{Chl-a, SSTa, Ekman transport and Bottom stress}

The results shown in the preceding section reveal the existence of episodic and seasonal upwelling within the SEQMCZ. In this section, the link between the forcing mechanisms (wind- and current driven) and the oceanic response as evident from changes in Chl-a and SSTa is explored further. A climatological view of daily Chl-a yields additional evidence for the existence

5 of different seasonal patterns in the northern and southern region (Fig. 10a). Chl-a increases to above the background level of $0.2 \mathrm{mg} \mathrm{m}^{-3}$ in both regions simultaneously from austral autumn to spring, but maximum values occur at different times (Fig. 10a). In the northern region, Chl-a exhibits a bimodal distribution with two maxima. The first maximum of about $0.42 \mathrm{mg} \mathrm{m}^{-}$ ${ }^{3}$ occurs in June and a second maximum of about $0.47 \mathrm{mg} \mathrm{m}^{-3}$ follows in August and September. In October, Chl-a values begin to decrease. In contrast, maximum Chl-a values in the southern region occur from April to July with a maximum of $0.42 \mathrm{mg}$

$10 \mathrm{~m}^{-3}$ in about mid-May. Increases and decreases in Chl-a appear to correspond to decreases and increases in SSTa (Fig. 10b).

The Chl-a and SSTa correlation is negative with a coefficient of 0.82 and 0.42 ( $95 \%$ confidence level) for the northern and southern section, respectively. These significant correlations highlight that most of the Chl-a increases are associated with a negative SSTa, particularly for the northern region. The concurrent occurrence of negative SSTa and enhanced Chl-a is in

15 agreement with the Ekman transport driven downwelling (upwelling) during the period of April to August (September to November) with differences in the latitudinal locations. Strong and persistent negative Ekman transport (inshore direction) is frequently observed during austral autumn and winter with a maximum transport of $-0.84 \mathrm{~m}^{2} \mathrm{~s}^{-1}$ and $-0.88 \mathrm{~m}^{2} \mathrm{~s}^{-1}$ in the northern and southern region, respectively (Fig. 10c). The transport changes direction to mostly positive in austral spring to summer and reaches its peak of 0.46 and $0.67 \mathrm{~m}^{2} \mathrm{~s}^{-1}$ for the northern and southern region, respectively (Fig. 10c). Note that negative

20 (positive) Ekman transport generates downwelling (upwelling) favourable condition.

The correlation between Ekman transport and Chl-a is generally negative and weak (strong), with a correlation coefficient of about 0.25 (0.60) and 95\% confidence level for the northern (southern) region. This suggests that Ekman transport influences the Chl-a response more in the southern than the northern region. However, the correlation between Ekman transport and SSTa

25 for both regions is weak (correlation coefficient < 0.05). The correlation becomes only significant (correlation coefficient $>$ 0.5) when the Ekman transport data are lagged by 33 and 112 days for the northern and southern region, respectively. The daily climatology of $\tau_{b}$ was identified as upwelling favourable $\left(\tau_{b}<-0.08 \mathrm{~N} \mathrm{~m}^{-2}\right)$ all year and particularly in the northern region (Fig. 10d). Moreover, $\tau_{b}$ lower than $-0.2 \mathrm{~N} \mathrm{~m}^{-2}$ develop intermittently during December to March and May to September (Fig. 10d). In the south, $\tau_{b}$ in lower than $-0.2 \mathrm{~N} \mathrm{~m}^{-2}$ primarily in January and February, April to June and September and 30 October. Nevertheless, we find that there is no significant correlation between $\tau_{b}$ and Chl-a or SSTa. 
Ocean Sci. Discuss., https://doi.org/10.5194/os-2018-142

Manuscript under review for journal Ocean Sci.

Discussion started: 9 January 2019

(c) Author(s) 2019. CC BY 4.0 License.

\section{Discussion and Conclusions}

Results derived from the analysis of four upwelling indices suggest that upwelling events occur in the SEQMCZ throughout the year, but due to seasonally varying forcing mechanisms. The number of total events is small as compared to the permanent upwelling systems of the world ocean. Nevertheless, this upwelling is crucial in driving regional and seasonally high

5 productivity and biodiversity in contrast to the otherwise very low background productivity of the oligotrophic waters of the EAC intensification zone.

The $\mathrm{UI}_{\mathrm{Chla}}$ and $\mathrm{UI}_{\mathrm{SST}}$ events detected from austral spring to summer in the northern region of the shelf characterise the Southeast Fraser Island Upwelling System which is predominately current-driven (Brieva et al., 2015). In contrast, the austral autumn

10 and winter $\mathrm{UI}_{\mathrm{Chla}}$ and $\mathrm{UISST}_{\mathrm{SST}}$ events detected in both the northern and southern regions of the shelf are not associated with the Southeast Fraser Island Upwelling System as proposed by Brieva et al. (2015). In addition, during austral autumn and winter, strong and persistent downwelling favourable southerly winds prevail in the region (Rossi et al., 2014; Wood et al., 2016; Azis Ismail et al., 2017) and current-driven uplift of cold and nutrient rich-water onto the inner shelf through the Ekman BBL may not necessarily reach the surface (Roughan and Middleton, 2002, 2004;Schaeffer et al., 2014).

15

The analysis of the $\mathrm{UI}_{\mathrm{w}}$ is consistent with earlier postulations of predominantly downwelling favourable conditions along the east coast of Australia (e.g. Rossi et al., 2014; Brieva et al., 2015; Wood et al., 2016; Azis Ismail et al., 2017). Although the bottom stress of the EAC is at its weakest during austral autumn and winter (Brieva et al. 2015), a small number of $\mathrm{UI}_{\mathrm{c}}$ events is found during April to June in both the northern and southern regions (Fig. 9). This potentially intensifies upwelling within

20 the BBL. $44 \%$ and $48 \%$ of $\mathrm{UI}_{\mathrm{c}}$ events occur during austral autumn and winter in the northern and southern region, respectively. In addition, $62 \%$ and $65 \%$ of $\mathrm{UI}_{\mathrm{w}}$ downwelling events occur in the northern and southern region from austral autumn to winter (Table 1), when the typical numbers of $\mathrm{UI}_{\mathrm{Chla}}$ and $\mathrm{UI}_{\mathrm{SsT}}$ events are at a maximum for both regions.

More than $50 \%$ of $\mathrm{UI}_{\text {Chla }}\left(52 \%\right.$ and $70 \%$ for the northern and southern region, respectively) and $\mathrm{UI}_{\mathrm{SST}}(52 \%$ and $69 \%$ for the northern and southern, respectively) occur from austral autumn to winter. These results suggest that the simultaneous downwelling favourable wind stress and persistent bottom stress may play an important role in driving Chl-a blooms and negative SSTa. Downwelling favourable wind stress coinciding with the EAC bottom stress are likely to establish convergence in the BBL that in turn creates a shelf break front (Fig. 11). The convergent flow could potentially bring cold and nutrient-rich slope waters close to or reach the surface. A similar mechanism was invoked to explain upwelling along the narrow shelf off 30 Sydney, Australia (Gibbs, 2000; Gibbs et al., 2000).

Downwelling favourable wind stress induces onshore flows within the surface Ekman layer (Figure 11). This is compensated by downwelling near the coast. A pressure gradient force directed toward the open ocean increases the inner-shelf positive 
Ocean Sci. Discuss., https://doi.org/10.5194/os-2018-142

Manuscript under review for journal Ocean Sci.

Discussion started: 9 January 2019

(c) Author(s) 2019. CC BY 4.0 License.

SSH anomaly and the establishment of a near coast geostrophic northerly flow in the direction of the wind. This northerly flow during the autumn to winter was previously identified and is referred to as the Fraser Gyre (Azis Ismail et al., 2017). Furthermore, the deeper offshore directed flow converges with an onshore flow that is associated with the EAC's bottom stress in the BBL over the shelf. This bottom flow convergence leads to a steepening of the frontal isopycnals and is likely to enhance

5 upwelling in the vicinity of the shelf (Carranza et al., 2017; Gibbs et al., 2000). Numerical modelling studies and observations for the EAC off Sydney, Australia, have shown that the interaction of downwelling favourable wind stress with the EAC can establish a flow convergence in the BBL (Gibbs et al. 1998; Gibbs, 2000; Gibbs et al., 2000).

Carranza et al. (2017) presented observational evidence of an upward nutrient pumping mechanism along a western boundary

10 current shelf-break. This upward nutrient transport has the potential to increase Chl-a over the shelf. Everett et al. (2014) demonstrated that the combination of current-driven upwelling and wind-driven downwelling can provide favourable conditions for the formation of upwelling that leads to observed positive Chl-a anomalies between $32^{\circ}$ and $33.5^{\circ} \mathrm{S}$. Thus, the bottom flow convergence potentially formed under simultaneous downwelling favourable winds and the along-shelf EAC explains also the occurrence of elevated Chl-a and cold surface waters found during austral autumn to winter in both northern

15 and southern regions of the SEQMCZ (see Fig. 2c and 3b). This situation is similar to those found in other WBC regimes including the Patagonian shelf (Carranza et al., 2017) and the Middle Atlantic Bight (Siedlecki et al., 2011).

A case study is investigated further to elucidate that this process appears to operate in the SEQMCZ (Figure 12). A specific upwelling event is discussed to distinguish factors that force upwelling ( $\tau_{b}$ and Ekman transport) from factors that result from

20 upwelling (enriched Chl-a, negative SSTa). An upwelling event from June 2007 is selected. During this period, $\tau_{b}(<-0.08 \mathrm{~N}$ $\mathrm{m}^{-2}$ ) promoting current-driven upwelling corrsponds to wind-driven downwelling and appears to result in a Chl-a bloom in southern region several days later.

Fig. 12a-12c provide observational evidence of the shelf-break front promoted upwelling in the southern region from June 10-

25 12, 2007. The upwelling event is characterised by a distinct band of enhanced Chl-a and is observed near the shelf-break at about $26.5^{\circ} \mathrm{S}$ in latitude. The Chl-a is more than $1.2 \mathrm{mg} \mathrm{m}^{-3}$ higher than those of the surrounding water. In addition, the filament of elevated Chl-a in the southern region is not connected with the high Chl-a observed in proximity of Fraser Island or the near-coast region. Thus, the high Chl-a values within the proximity of the shelf-break appear to originate locally (Fig 12a12c). It is the shelf-break upwelling that carries nutrient-rich water from the BBL to the euphotic layer and increases primary 30 productivity.

Values for $\tau_{b}$ and Ekman transport support the mechanism of shelf-break front induced upwelling (Fig. 12d-12e). Before the on-set of the Chl-a bloom, $\tau_{b}$ is consistently lower than $-0.08 \mathrm{~N} \mathrm{~m}^{-2}$ from June $1-9$ at $26.5^{\circ} \mathrm{S}$ and even reached a minimum value of $-0.4 \mathrm{~N} \mathrm{~m}^{-2}$ between 1-2 June 2007. At the same time, wind-driven Ekman surface layer transport is negative indicating 
Ocean Sci. Discuss., https://doi.org/10.5194/os-2018-142

Manuscript under review for journal Ocean Sci.

Discussion started: 9 January 2019

(c) Author(s) 2019. CC BY 4.0 License.

persistent downwelling favourable conditions. Upwelling favourable $\tau_{b}$ and downwelling favourable surface Ekman transports are likely to induce a flow convergence in the BBL that leads to upwelling of nutrient-rich water into the surface layer, which is followed by an increase in Chl-a about a week later.

5 Given the seasonally reoccurring upwelling events, it is no surprise that the region is characterized by enhanced pelagic productivity (Evans et al., 2017) and was previously identified as a key ecological site off Australia's east coast (Dambacher et al., 2012). Neira and Keane (2008) suggest a relationship between upwelling of cooler nutrient-rich water and an increase in planktonic biomass, including for example, the large abundances of blue mackerel eggs during austral winter and spring. Frequent upwelling events of low intensity boost primary production, enhance productivity and establish the region as an

10 important fishery (e.g. Young et al., 2011).

This study uses complementary upwelling indices derived from remotely-sensed and reanalysis data. In-situ observations from the study site do not exist. Thus, it is suggested that future work is required to investigate bio-physical processes and explore upwelling indices using in-situ measurements along with high-resolution modelling. In addition, some limitations to this study

15 need to be acknowledged and taken into account in interpreting the results. The analysis presented here focuses largely on the seasonal climatology and mean state of upwelling off southeast Queensland, however, we also identify much longer lasting negative SST anomalies persisting for about 2 months (see lower panel of Fig. 5) during the period of July to August each year. This is the period when cyclonic eddies frequently encroach onto the shelf (Everett et al., 2014; Ribbe et al., 2018). The role of cyclonic frontal eddies in raising Chl-a and cooling shelf water is not addressed in this study. Yet, a recent study by

20 Ribbe et al. (2018) observed frontal cyclonic eddies off SEQMCZ during austral autumn and winter that are characterised by elevated Chl-a and cold SST. This is indicative of coastal water entrainment and possibly eddy-driven upwelling. All those upwelling factors (wind, currents, frontal eddies) and processes (surface/bottom convergence/divergence) may occur concomitantly, superimposing their hydrographic signatures. Hence, future studies should integrate both numerical and observational approaches to better understand how all the processes interact and how the shelf waters ultimately respond.

25 Data availability

The long-term Chl-a and SST data are provided by the Integrated Marine Observing System (IMOS) and can be retrieved from the Australian Ocean Data Network at https://portal.aodn.org.au/. The scatterometer QuikSCAT and ASCAT data are publicly available via FTP at ftp://ftp.remss.com/qscat/bmaps_v04/ and ftp://ftp.remss.com/ascat/metopa/bmaps_v02.1/, respectively. The ocean reanalysis Bluelink version 3.5 (BRAN3p5) data are available via OPENDAP at 30 http://dapds00.nci.org.au/thredds/catalog/gb6/BRAN/BRAN3p5/OFAM/catalog.html. 
Ocean Sci. Discuss., https://doi.org/10.5194/os-2018-142

Manuscript under review for journal Ocean Sci.

Discussion started: 9 January 2019

(c) Author(s) 2019. CC BY 4.0 License.

\section{Author contributions}

Azis Ismail compiled the datasets, performed the analysis, interpreted the results and wrote the draft manuscript. Ribbe was involved in planning, supervising the research, designing the figures and structure of the manuscript and revising sections of the manuscript. Ribbe, Karstensen and Rossi aided in interpreting the results and worked on the manuscript. All authors

5 provided critical feedback and contributed to the final writing of the manuscript.

\section{Competing interest}

The authors declare that they have no conflict of interest.

\section{Acknowledgements}

The authors would like to thank IMOS colleagues, the NASA Ocean Vector Winds Science team, and the Bluelink team for

10 providing access to the data used in this study. Mr. Mochamad Furqon Azis Ismail acknowledges support from the Research Centre for Oceanography - Indonesian Institute of Sciences (RCO - LIPI) as well as financial support from the Ministry of Research, Technology and Higher Education of the Republic of Indonesia (Grant No. 8245-ID) and its Research and Innovation in Science and Technologies Program (RISET-Pro).

\section{References}

15 Aguiar, A., Cirano, M., Pereira, J., and Marta-Almeida, M.: Upwelling processes along a western boundary current in the Abrolhos-Campos region of Brazil, Continental Shelf Research, 85, 42-59, 2014.

Alvarez, I., Gomez-Gesteira, M., Lorenzo, M., Crespo, A., and Dias, J.: Comparative analysis of upwelling influence between the western and northern coast of the Iberian Peninsula, Continental Shelf Research, 31, 388-399, 2011.

Armbrecht, L. H., Schaeffer, A., Roughan, M., and Armand, L. K.: Interactions between seasonality and oceanic forcing drive

20 the phytoplankton variability in the tropical-temperate transition zone ( $30 \mathrm{~S})$ of Eastern Australia, Journal of Marine Systems, 144, 92-106, 2015.

Azis Ismail, M. F., Ribbe, J., Karstensen, J., Lemckert, C., Lee, S., and Gustafson, J.: The Fraser Gyre: A cyclonic eddy off the coast of eastern Australia, Estuarine Coastal Shelf Science, 192, 72-85, https://doi.org/10.1016/j.ecss.2017.04.031, 2017.

Bakun, A., and Nelson, C. S.: The seasonal cycle of wind-stress curl in subtropical eastern boundary current regions, Journal 25 of Physical Oceanography, 21, 1815-1834, 1991.

Bentamy, A., Grodsky, S. A., Carton, J. A., Croizé-Fillon, D., and Chapron, B.: Matching ASCAT and QuikSCAT winds, Journal of Geophysical Research: Oceans, 117, 2012. 
Ocean Sci. Discuss., https://doi.org/10.5194/os-2018-142

Manuscript under review for journal Ocean Sci.

Discussion started: 9 January 2019

(c) Author(s) 2019. CC BY 4.0 License.

Brieva, D., Ribbe, J., and Lemckert, C.: Is the East Australian Current causing a marine ecological hot-spot and an important fisheries near Fraser Island, Australia?, Estuarine Coastal Shelf Science, 153, 121-134, 10.1016/j.ecss.2014.12.012, 2015.

Brink, K. H.: Cross-Shelf Exchange, Annual Review of Marine Science, 8, 59-78, 10.1146/annurev-marine-010814-015717, 2016.

5 Carranza, M. M., Gille, S. T., Piola, A. R., Charo, M., and Romero, S. I.: Wind modulation of upwelling at the shelf-break front off Patagonia: Observational evidence, Journal of Geophysical Research: Oceans, 122, 2401-2421, 10.1002/2016JC012059, 2017.

Chen, Z., Yan, X.-H., Jo, Y.-H., Jiang, L., and Jiang, Y.: A study of Benguela upwelling system using different upwelling indices derived from remotely sensed data, Continental Shelf Research, 45, 27-33, http://dx.doi.org/10.1016/j.csr.2012.05.013,

102012.

Condie, S. A., and Dunn, J. R.: Seasonal characteristics of the surface mixed layer in the Australasian region: implications for primary production regimes and biogeography, Marine and Freshwater Research, 57, 569-590, 2006.

Cropper, T. E., Hanna, E., and Bigg, G. R.: Spatial and temporal seasonal trends in coastal upwelling off Northwest Africa, 1981-2012, Deep Sea Research Part I: Oceanographic Research Papers, 86, 94-111, 2014.

15 Evans, K., Bax, N., and Smith, D. C.: Australia state of the environment 2016: marine environment, independent report to the Australian Government Minister for the Environment and Energy, Australian Government Department of the Environment and Energy, Canberra, 2017.

Everett, J. D., Baird, M. E., Roughan, M., Suthers, I. M., and Doblin, M. A.: Relative impact of seasonal and oceanographic drivers on surface chlorophyll a along a Western Boundary Current, Progress in Oceanography, 120, 340-351,

20 http://dx.doi.org/10.1016/j.pocean.2013.10.016, 2014.

Gibbs, M. T., Middleton, J. H., and Marchesiello, P.: Baroclinic response of Sydney shelf waters to local wind and deep ocean forcing, Journal of Physical Oceanography, 28, 178-190, 1998.

Gibbs, M. T.: Elevated chlorophyll a concentrations associated with a transient shelfbreak front in a western boundary current at Sydney, south-eastern Australia, Marine and Freshwater Research, 51, 733-737, 2000.

25 Gibbs, M. T., Marchesiello, P., and Middleton, J. H.: Observations and simulations of a transient shelfbreak front over the narrow shelf at Sydney, southeastern Australia, Continental Shelf Research, 20, 763-784, 2000.

Griffin, C., Beggs, H., and Majewski, L.: GHRSST compliant AVHRR SST products over the Australian region, Bureau of Meteorology, Melbourne, 151, 2017.

IMOS, 2018. Chlorophyll-a, Sea Surface Temperature and Sea Surface Height. Access: March 17.

30 https://portal.aodn.org.au/.

Jayaram, C., and Kumar, P. K. D.: Spatio-temporal variability of upwelling along the southwest coast of India based on satellite observations, Continental Shelf Research, 156, 33-42, https://doi.org/10.1016/j.csr.2018.02.003, 2018.

Kämpf, J.: Phytoplankton blooms on the western shelf of Tasmania: evidence of a highly productive ecosystem, Ocean Science, $11,1-11,2015$. 
Ocean Sci. Discuss., https://doi.org/10.5194/os-2018-142

Manuscript under review for journal Ocean Sci.

Discussion started: 9 January 2019

(c) Author(s) 2019. CC BY 4.0 License.

Kämpf, J., and Chapman, P.: Upwelling Systems of the World, Springer, 2016.

Keane, J. P., and Neira, F. J.: Larval fish assemblages along the south-eastern Australian shelf: linking mesoscale non-depthdiscriminate structure and water masses, Fisheries Oceanography, 17, 263-280, 2008.

Lamont, T., García-Reyes, M., Bograd, S. J., van der Lingen, C. D., and Sydeman, W. J.: Upwelling indices for comparative

5 ecosystem studies: Variability in the Benguela Upwelling System, Journal of Marine Systems, https://doi.org/10.1016/j.jmarsys.2017.05.007, 2017.

Leber, G. M., Beal, L. M., and Elipot, S.: Wind and Current Forcing Combine to Drive Strong Upwelling in the Agulhas Current, Journal of Physical Oceanography, 47, 123-134, 2017.

Middleton, J. H., Coutis, P., Griffin, D. A., Macks, A., McTaggart, A., Merrifield, M., and Nippard, G. J.: Circulation and

10 water mass characteristics of the southern Great Barrier Reef, Marine and Freshwater Research, 45, 1-18, 1994.

Neira, F. J., and Keane, J. P.: Ichthyoplankton-based spawning dynamics of blue mackerel (Scomber australasicus) in southeastern Australia: links to the East Australian Current, Fisheries Oceanography, 17, 281-298, 2008.

Oke, Brassington, G. B., Griffin, D. A., and Schiller, A.: The Bluelink ocean data assimilation system (BODAS), Ocean Modelling, 21, 46-70, 2008.

15 Oke, Sakov, P., Cahill, M. L., Dunn, J. R., Fiedler, R., Griffin, D. A., Mansbridge, J. V., Ridgway, K. R., and Schiller, A.: Towards a dynamically balanced eddy-resolving ocean reanalysis: BRAN3, Ocean Modelling, 67, 52-70, 2013.

Oke, P. R., and Griffin, D. A.: The cold-core eddy and strong upwelling off the coast of New South Wales in early 2007, Deep Sea Research Part II: Topical Studies in Oceanography, 58, 574-591, 2011.

Ribbe, J.: Hervey Bay and its estuaries, in: Estuaries of Australia in 2050 and beyond, Springer, 185-201, 2014.

20 Ribbe, J., Toaspern, L., Wolff, J.-O., and Ismail, M. F. A.: Frontal Eddies along a Western Boundary Current, Continental Shelf Research, 165, 51-59, 2018.

Ridgway, K. R., and Godfrey, J. S.: Seasonal cycle of the East Australian Current, Journal of Geophysical Research, 102, 22921, 10.1029/97jc00227, 1997.

Ridgway, K. R., and Dunn, J. R.: Mesoscale structure of the mean East Australian Current System and its relationship with

25 topography, Progress in Oceanography, 56, 189-222, 10.1016/s0079-6611(03)00004-1, 2003.

Rossi, V., Schaeffer, A., Wood, J., Galibert, G., Morris, B., Sudre, J., Roughan, M., and Waite, A. M.: Seasonality of sporadic physical processes driving temperature and nutrient high-frequency variability in the coastal ocean off southeast Australia, Journal of Geophysical Research: Oceans, 119, 445-460, 2014.

Roughan, M., and Middleton, J. H.: A comparison of observed upwelling mechanisms off the east coast of Australia, 30 Continental Shelf Research, 22, 2551-2572, 2002.

Roughan, M., and Middleton, J. H.: On the East Australian Current: Variability, encroachment, and upwelling, Journal of Geophysical Research, 109, 10.1029/2003jc001833, 2004.

Schaeffer, A., Roughan, M., and Morris, B. D.: Cross-shelf dynamics in a western boundary current regime: Implications for upwelling, Journal of Physical Oceanography, 43, 1042-1059, 2013. 
Ocean Sci. Discuss., https://doi.org/10.5194/os-2018-142

Manuscript under review for journal Ocean Sci.

Discussion started: 9 January 2019

(C) Author(s) 2019. CC BY 4.0 License.

Discussions

(c) (†)

Schaeffer, A., Roughan, M., and Wood, J.: Observed bottom boundary layer transport and uplift on the continental shelf adjacent to a western boundary current, Journal of Geophysical Research: Oceans, 119, 4922-4939, 2014.

Schaeffer, A., and Roughan, M.: Influence of a western boundary current on shelf dynamics and upwelling from repeat glider deployments, Geophysical Research Letters, 42, 121-128, 2015.

5 Siedlecki, S. A., Archer, D. E., and Mahadevan, A.: Nutrient exchange and ventilation of benthic gases across the continental shelf break, Journal of Geophysical Research: Oceans, 116, C06023, 10.1029/2010JC006365, 2011.

Wang, D., Gouhier, T. C., Menge, B. A., and Ganguly, A. R.: Intensification and spatial homogenization of coastal upwelling under climate change, Nature, 518, 390-394, 2015.

Wang, X. H., Bhatt, V., and Sun, Y.-J.: Study of seasonal variability and heat budget of the East Australian Current using two

10 eddy-resolving ocean circulation models, Ocean Dynamics, 63, 549-563, 2013.

Ward, T., Staunton-Smith, J., Hoyle, S., and Halliday, I.: Spawning patterns of four species of predominantly temperate pelagic fishes in the sub-tropical waters of southern Queensland, Estuarine Coastal Shelf Science, 56, 1125-1140, 2003.

Wijffels, S. E., Beggs, H., Griffin, C., Middleton, J. F., Cahill, M., King, E., Jones, E., Feng, M., Benthuysen, J. A., and Steinberg, C. R.: A fine spatial-scale sea surface temperature atlas of the Australian regional seas (SSTAARS): Seasonal

15 variability and trends around Australasia and New Zealand revisited, Journal of Marine Systems, 187, 156-196, 2018.

Wood, J., Schaeffer, A., Roughan, M., and Tate, P.: Seasonal variability in the continental shelf waters off southeastern Australia: Fact or fiction?, Continental Shelf Research, 112, 92-103, 2016.

Young, J., Hobday, A., Campbell, R., Kloser, R., Bonham, P., Clementson, L., and Lansdell, M.: The biological oceanography of the East Australian Current and surrounding waters in relation to tuna and billfish catches off eastern Australia, Deep Sea

Research Part II: Topical Studies in Oceanography, 58, 720-733, 2011.

Table 1. Total number, average per year, and percentage of UIsst, UIChla, UI $I_{w}$ and $U_{I_{c}}$ identified austral autumn to winter events at $25.5^{\circ} \mathrm{S}$ and $26.5^{\circ} \mathrm{S}$.

\begin{tabular}{|c|c|c|c|c|c|c|c|c|c|c|}
\hline & \multicolumn{2}{|c|}{ Number of $\mathbf{U} \mathbf{I}_{\text {Chla }}$} & \multicolumn{2}{|c|}{ Number of UI IST } & \multicolumn{2}{|c|}{$\begin{array}{c}\text { Number of } \mathrm{UI}_{\mathrm{w}} \\
\text { (upwelling) }\end{array}$} & \multicolumn{2}{|c|}{$\begin{array}{l}\text { Number of } \mathbf{U I}_{\mathrm{w}} \\
\text { (downwelling) }\end{array}$} & \multicolumn{2}{|c|}{ Number of $\mathbf{U} \mathbf{I}_{\mathbf{c}}$} \\
\hline & $25.5^{\circ} \mathrm{S}$ & $26.5^{\circ} \mathrm{S}$ & $25.5^{\circ} \mathrm{S}$ & $26.5^{\circ} S$ & $25.5^{\circ} \mathrm{S}$ & $26.5^{\circ} \mathrm{S}$ & $25.5^{\circ} \mathrm{S}$ & $26.5^{\circ} \mathrm{S}$ & $25.5^{\circ} \mathrm{S}$ & $26.5^{\circ} \mathrm{S}$ \\
\hline Total & 145 & 99 & 42 & 42 & 43 & 57 & 132 & 129 & 79 & 64 \\
\hline $\begin{array}{l}\text { Average per } \\
\text { year }\end{array}$ & 10.3 & 7.1 & 3 & 3 & 3.1 & 4.1 & 9.4 & 9.2 & 6.6 & 5.3 \\
\hline $\begin{array}{c}\text { Percentage } \\
\text { during autumn } \\
\text { to winter }(\%)\end{array}$ & 52 & 70 & 52 & 69 & 9 & 7 & 62 & 65 & 44 & 48 \\
\hline
\end{tabular}

\section{Figure captions}

Figure 1. The geographic location of the study site along the north-east coast of Australia. Indicated are key physical oceanographic features. $40 \mathrm{~m}$ (dotted), $200 \mathrm{~m}$ (dashed) and $1000 \mathrm{~m}$ (solid) isobaths are indicated. 
Ocean Sci. Discuss., https://doi.org/10.5194/os-2018-142

Manuscript under review for journal Ocean Sci.

Discussion started: 9 January 2019

(c) Author(s) 2019. CC BY 4.0 License.

Figure 2. Mean monthly climatology of Chl-a $\left(\mathrm{mg} \mathrm{m}^{-3}\right)$ and for austral (a) spring to summer, (b) autumn to winter and (c) the difference of data between (a) and (b). White areas indicate Chl-a values of $<0.2 \mathrm{mg} \mathrm{m}^{-3}$ which is the background value of EAC advected Coral Sea water.

Figure 3. Mean monthly climatology of SST anomaly $\left({ }^{\circ} \mathrm{C}\right.$ ) and for austral (a) spring to summer and (b) autumn to winter.

5 Figure 4. Chl-a $\left(\mathrm{mg} \mathrm{m}^{-3}\right.$ ) across sections at (a) $25.5^{\circ} \mathrm{S}$ and (b) $26.5^{\circ} \mathrm{S}$, which represent the northern and southern regions respectively. Distance $0 \mathrm{~km}$ is located at the $40 \mathrm{~m}$ isobath.

Figure 5. Negative SST $\left({ }^{\circ} \mathrm{C}\right)$ anomaly averaged zonally between the $40 \mathrm{~m}$ and $200 \mathrm{~m}$ isobath and for the period 1993 to 2016 (upper panel) and an enlarged period of 2003 to 2009 in the lower panel.

Figure 6. Cumulative number of $\mathrm{UI}_{\mathrm{Chla}}$ events at (a) $25.5^{\circ} \mathrm{S}$ and (b) $26.5^{\circ} \mathrm{S}$.

10 Figure 7. Cumulative number of $\mathrm{UI}_{\mathrm{SST}}$ events at (a) $25.5^{\circ} \mathrm{S}$ and (b) $26.5^{\circ} \mathrm{S}$.

Figure 8. Cumulative number of $\mathrm{UI}_{\mathrm{w}}$ events at $(\mathrm{a}, \mathrm{b}) 25.5^{\circ} \mathrm{S}$ and (c, d) $26.5^{\circ} \mathrm{S}$.

Figure 9. Cumulative number of $\mathrm{UI}_{\mathrm{c}}$ events at (a) $25.5^{\circ} \mathrm{S}$ and (b) $26.5^{\circ} \mathrm{S}$.

Figure 10. (a) Chl-a $\left(\mathrm{mg} \mathrm{m}^{-3}\right)$, (b) SSTa $\left({ }^{\circ} \mathrm{C}\right)$, (c) Ekman transport $\left(\mathrm{m}^{2} \mathrm{~s}^{-1}\right)$ and (d) $\tau_{b}\left(\mathrm{~N} \mathrm{~m}^{-2}\right)$ at $25.5^{\circ} \mathrm{S}$ (blue line) and $26.5^{\circ} \mathrm{S}$ (red line). The dotted line in Fig. 10a corresponds to the background value of Chl-a in SEQMCZ, while the dotted line at -0.08

$15\left(\mathrm{~N} \mathrm{~m}^{-2}\right)$ in Fig. 10d indicates the threshold value of $\tau_{b}$ considered upwelling favourable (Everett et al., 2014).

Figure 11. Schematic cross-shelf diagram of flow convergence that is formed under simultaneous onshore flow due to EAC's bottom stress and offshore flow due to downwelling favourable wind stress in the BBL. The flow convergence establishes a shelf break front which promotes uplift of nutrients.

Figure 12. Chl-a $\left(\mathrm{mg} \mathrm{m}^{-3}\right)$ for June (a) 10, (b) 11, and (c) 12, 2007. Cloud coverage limits the number of days availalbe for

20 analysis. Daily time series of (d) $\tau_{b}\left(\mathrm{~N} \mathrm{~m}^{-2}\right)$ and (e) Ekman transport $\left(\mathrm{m}^{2} \mathrm{~s}^{-1}\right)$ at $25.5^{\circ} \mathrm{S}$ (blue line) and $26.5^{\circ} \mathrm{S}$ (red line) from 25 May to 30 June 2007. The dotted black line at $-0.08\left(\mathrm{~N} \mathrm{~m}^{-2}\right)$ in Fig. 12d indicates the threshold value of $\tau_{b}$ considered as upwelling favourable (Everett et al., 2014). 
Ocean Sci. Discuss., https://doi.org/10.5194/os-2018-142

Manuscript under review for journal Ocean Sci.

Discussion started: 9 January 2019

(c) Author(s) 2019. CC BY 4.0 License.

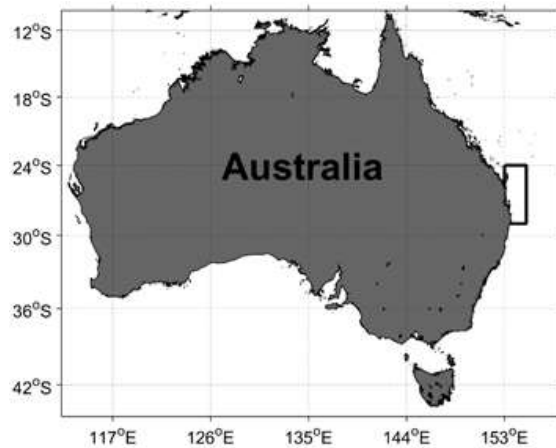

1. East Australian Current

2. Southeast Fraser Island Upwelling System

3. Fraser Gyre

4. Fraser Island

5. Hervey Bay

6. Moreton Island

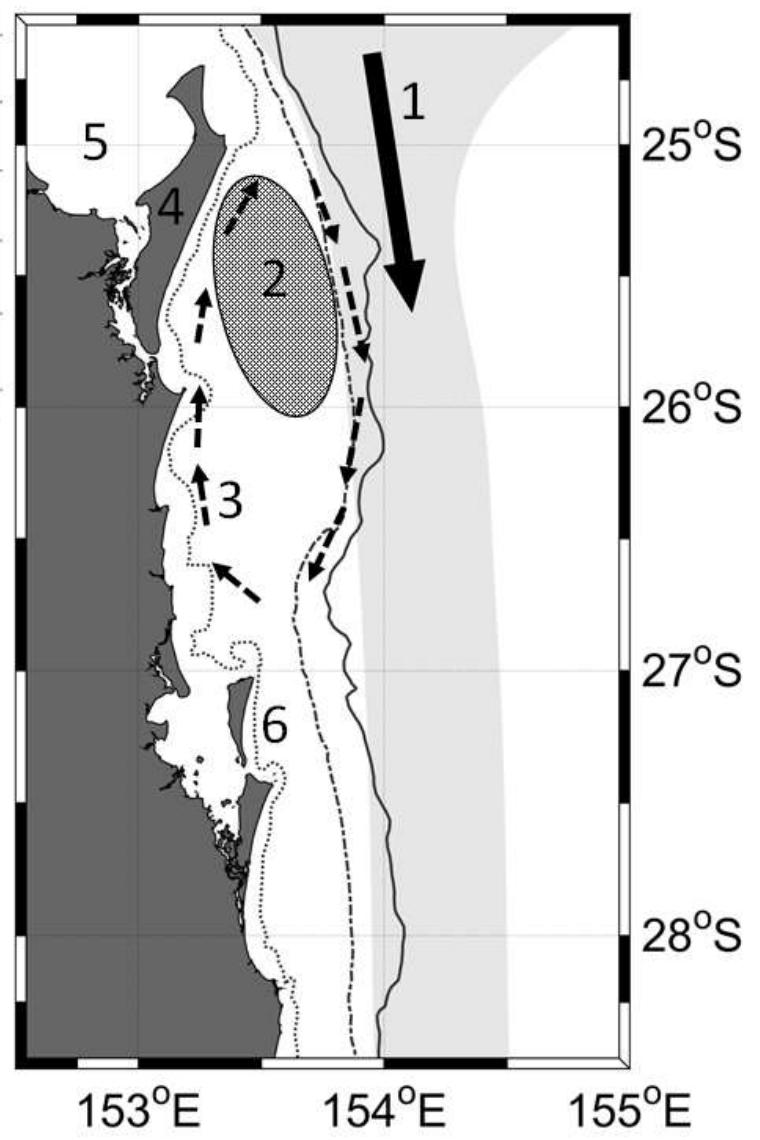

Figure 1. The geographic location of the study site along the north-east coast of Australia. Indicated are key physical oceanographic features. $40 \mathrm{~m}$ (dotted), $200 \mathrm{~m}$ (dashed) and $1000 \mathrm{~m}$ (solid) isobaths are indicated. 
Ocean Sci. Discuss., https://doi.org/10.5194/os-2018-142

Manuscript under review for journal Ocean Sci.

Discussion started: 9 January 2019

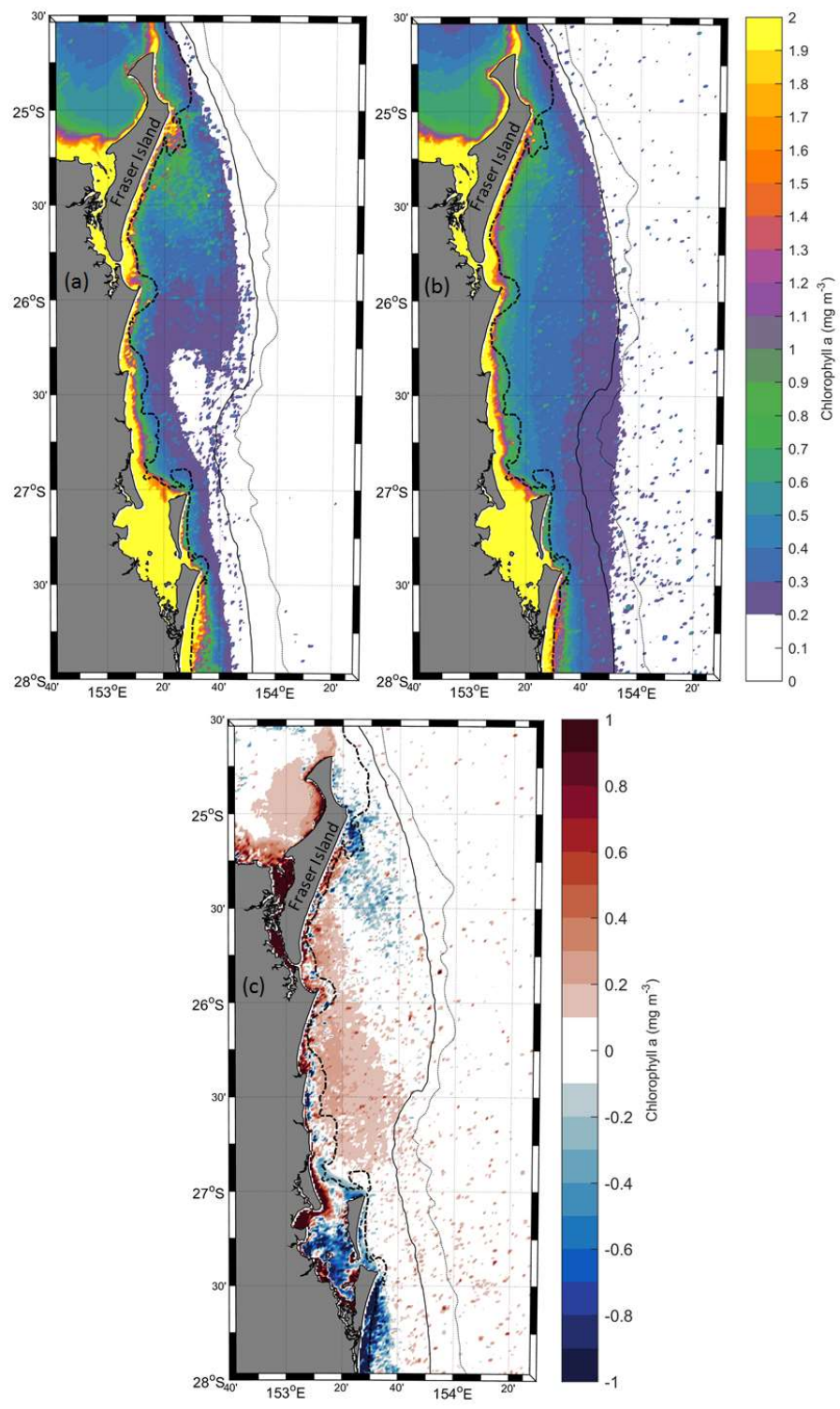

Figure 2. Mean monthly climatology of $\mathrm{Chl}-\mathrm{a}\left(\mathrm{mg} \mathrm{m}^{-3}\right)$ for the SEQMCZ during 2003-2016 and for austral (a) spring to summer, (b) autumn to winter and (c) the difference of data between (a) and (b). White areas indicate Chl-a values of $<0.2 \mathrm{mg} \mathrm{m}^{-3} \mathrm{which}$ is the background value of East Australian Currents (EAC) advected Coral Sea water. 
Ocean Sci. Discuss., https://doi.org/10.5194/os-2018-142

Manuscript under review for journal Ocean Sci.

Discussion started: 9 January 2019

Ocean Science

(c) Author(s) 2019. CC BY 4.0 License.

Discussions

(c) (1)

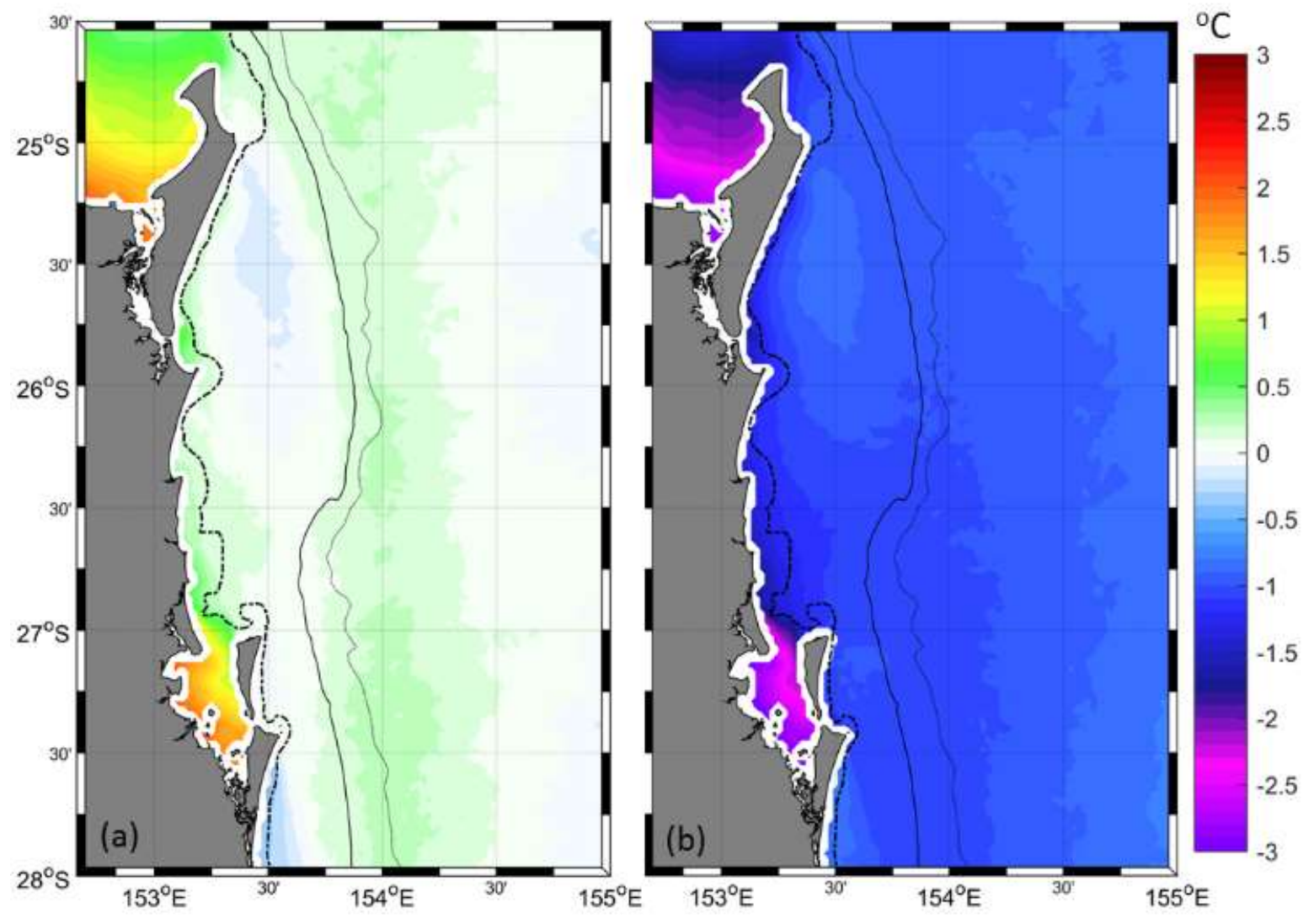

Figure 3. Mean monthly climatology of SST anomaly $\left({ }^{\circ} \mathrm{C}\right)$ and for austral (a) spring to summer and (b) autumn to winter. 
Ocean Sci. Discuss., https://doi.org/10.5194/os-2018-142

Manuscript under review for journal Ocean Sci.

Discussion started: 9 January 2019

(c) Author(s) 2019. CC BY 4.0 License.

(c) (1)

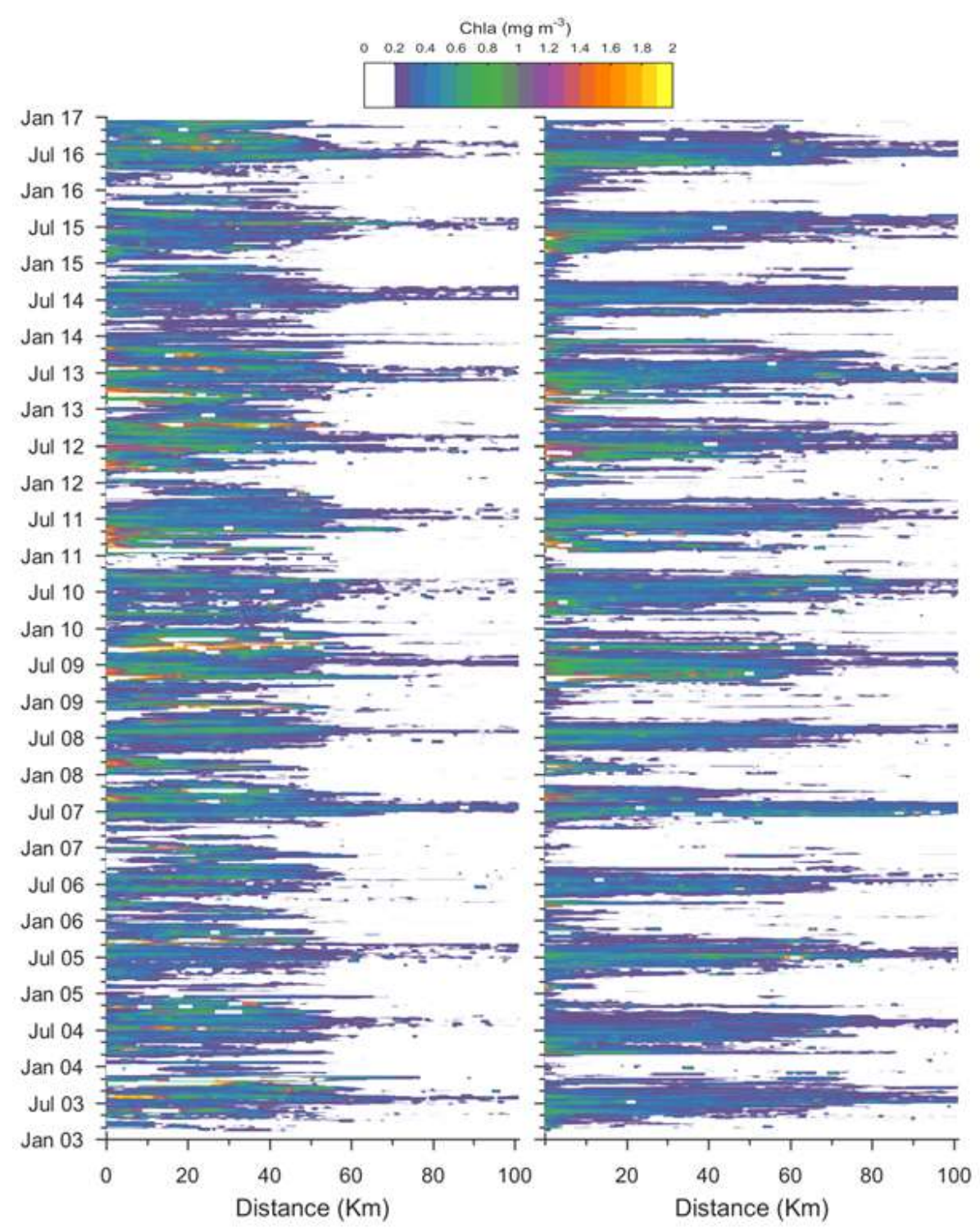

Figure 4. Chl-a $\left(\mathrm{mg} \mathrm{m}^{-3}\right)$ across sections at (a) $25.5^{\circ} \mathrm{S}$ and (b) $26.5^{\circ} \mathrm{S}$, which represent the northern and southern regions respectively. Distance $0 \mathrm{~km}$ is located at the $40 \mathrm{~m}$ isobath. 
Ocean Sci. Discuss., https://doi.org/10.5194/os-2018-142

Manuscript under review for journal Ocean Sci.

Discussion started: 9 January 2019

(c) Author(s) 2019. CC BY 4.0 License.

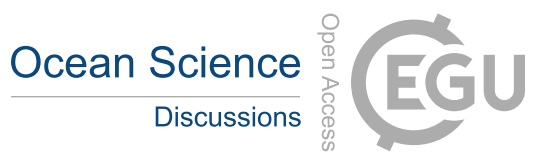

(c) (i)

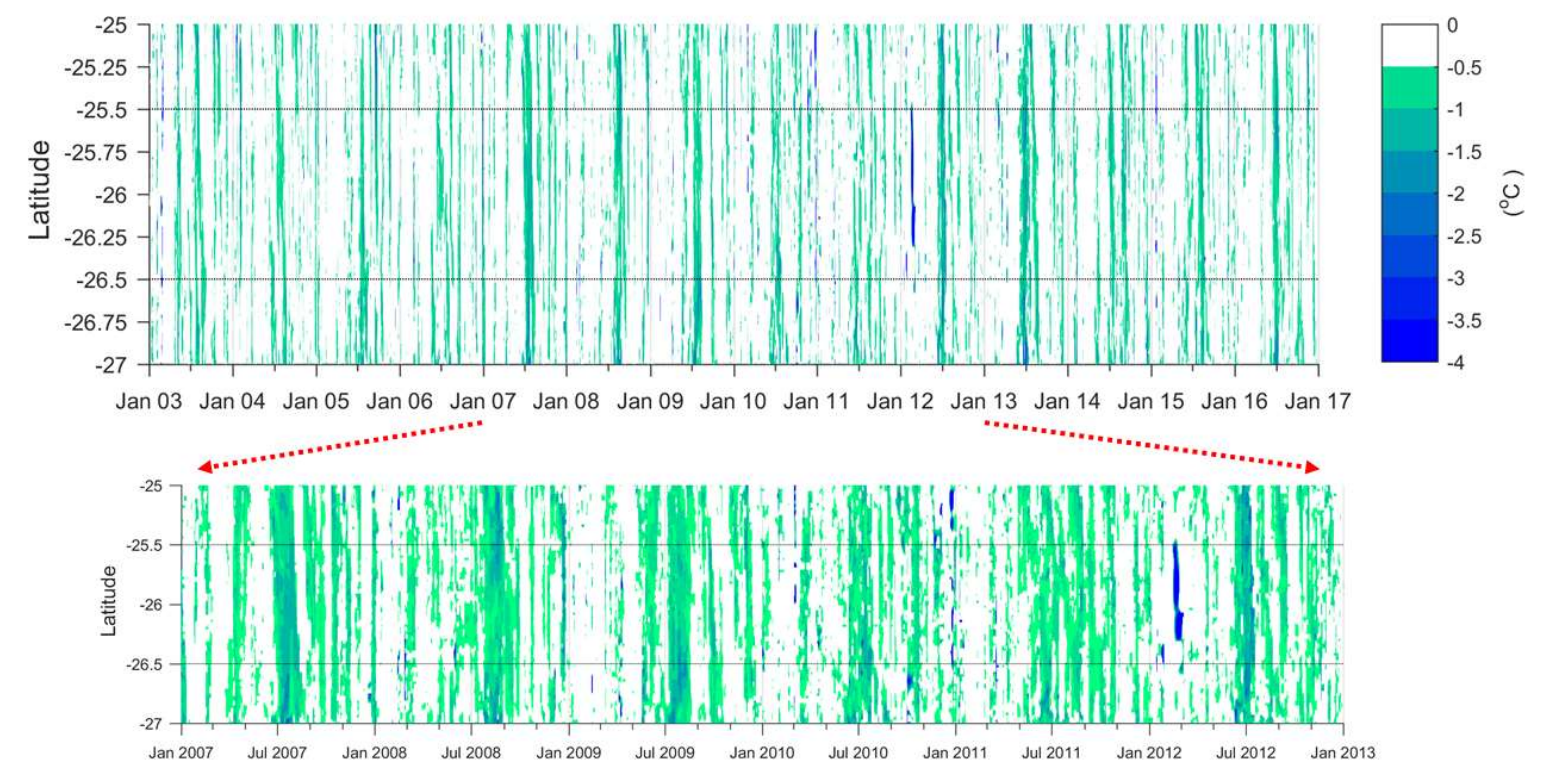

Figure 5. Negative SST $\left({ }^{\circ} \mathrm{C}\right)$ anomaly averaged zonally between the $40 \mathrm{~m}$ and $200 \mathrm{~m}$ isobath and for the period 1993 to 2016 (upper panel) and an enlarged period of 2003 to 2009 in the lower panel. 
Ocean Sci. Discuss., https://doi.org/10.5194/os-2018-142

Manuscript under review for journal Ocean Sci.

Discussion started: 9 January 2019
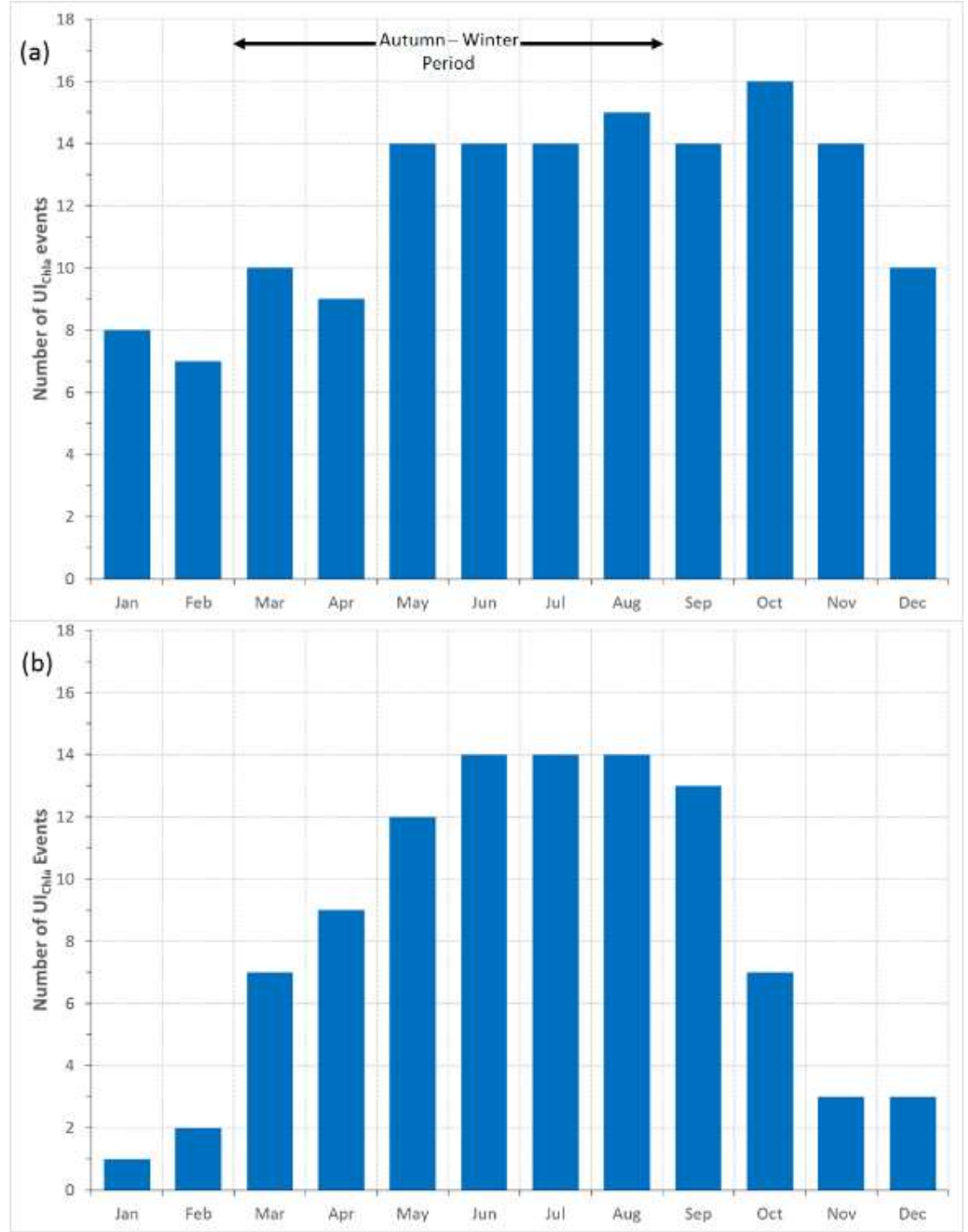

Figure 6. Cumulative number of UI $I_{C h l a}$ events at (a) $25.5^{\circ} \mathrm{S}$ and (b) $26.5^{\circ} \mathrm{S}$. 
Ocean Sci. Discuss., https://doi.org/10.5194/os-2018-142

Manuscript under review for journal Ocean Sci.

Discussion started: 9 January 2019

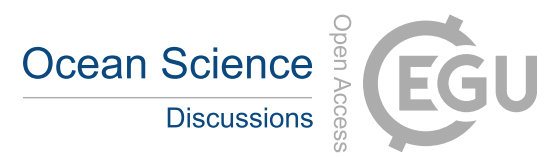

(c) Author(s) 2019. CC BY 4.0 License.

(c) (1)
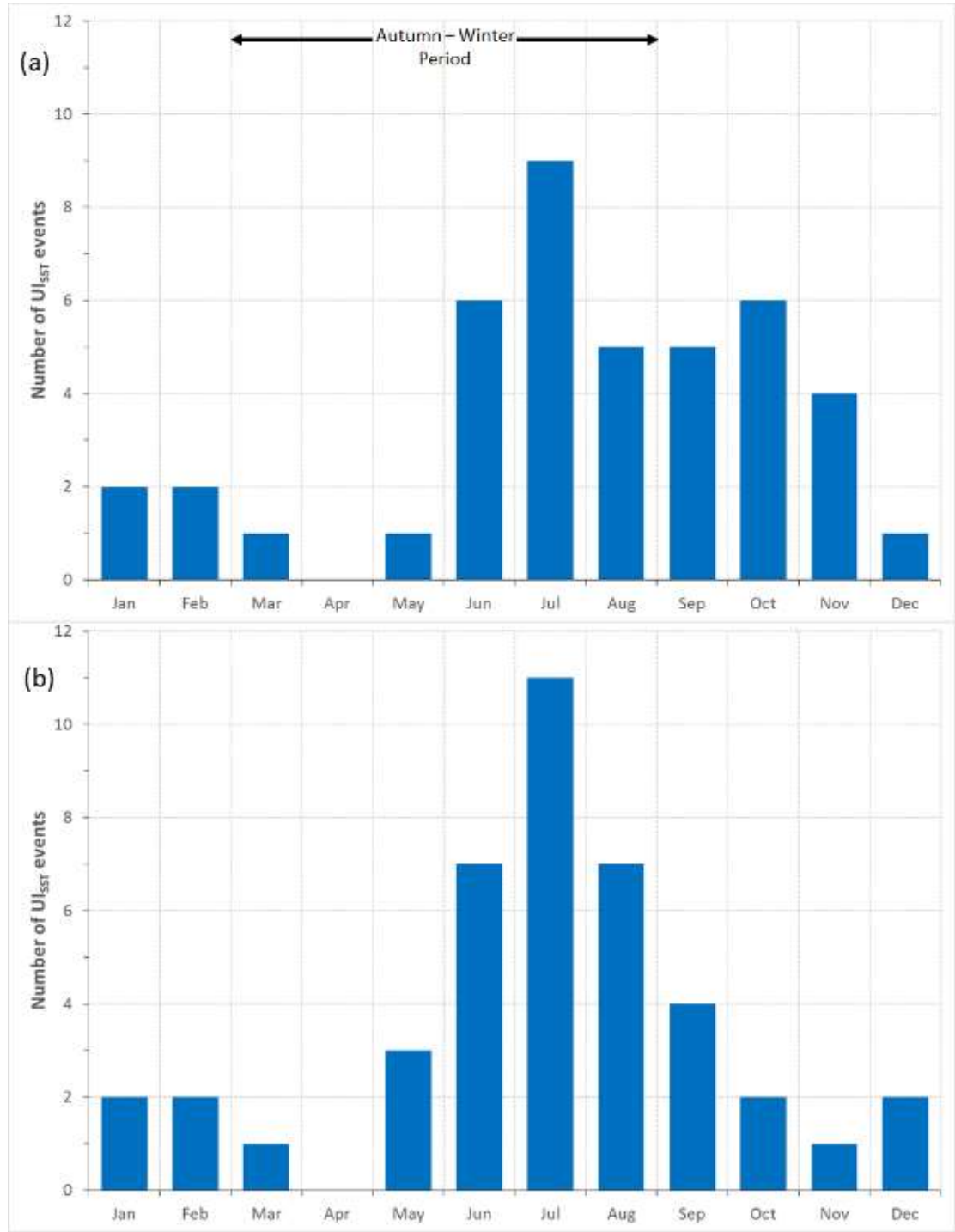

Figure 7. Cumulative number of UIsst events at (a) $25.5^{\circ} \mathrm{S}$ and (b) $26.5^{\circ} \mathrm{S}$. 
Ocean Sci. Discuss., https://doi.org/10.5194/os-2018-142

Manuscript under review for journal Ocean Sci.

Discussion started: 9 January 2019

(c) Author(s) 2019. CC BY 4.0 License.

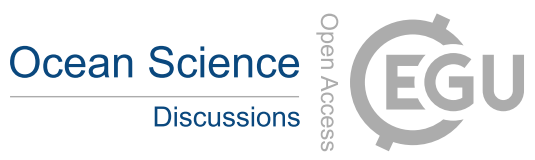

(c) (i)
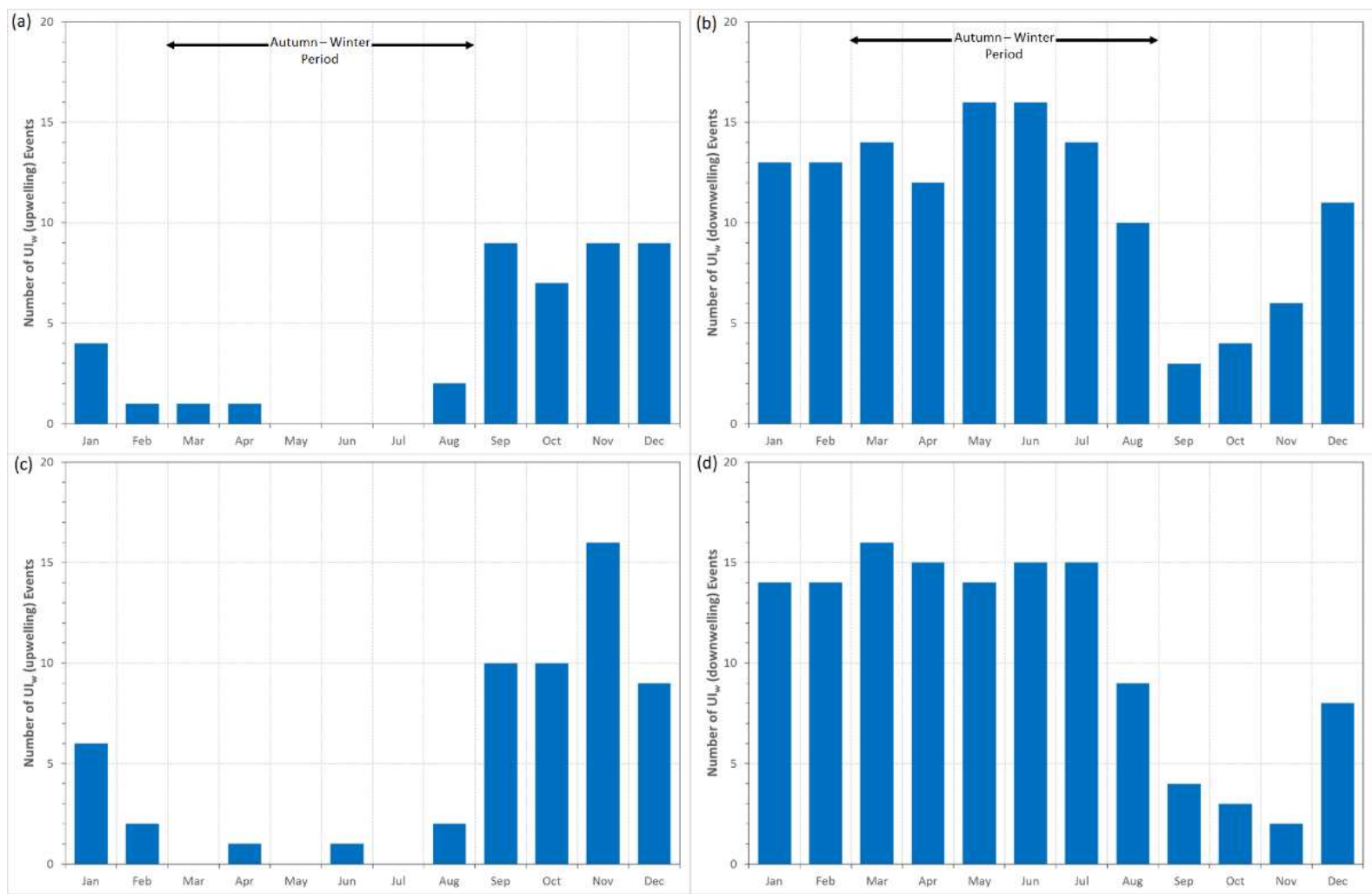

Figure 8. Cumulative number of $\mathrm{UI}_{w}$ events at $(a, b) 25.5^{\circ} \mathrm{S}$ and (c, d) $26.5^{\circ} \mathrm{S}$. 
Ocean Sci. Discuss., https://doi.org/10.5194/os-2018-142

Manuscript under review for journal Ocean Sci.

Discussion started: 9 January 2019

(c) Author(s) 2019. CC BY 4.0 License.
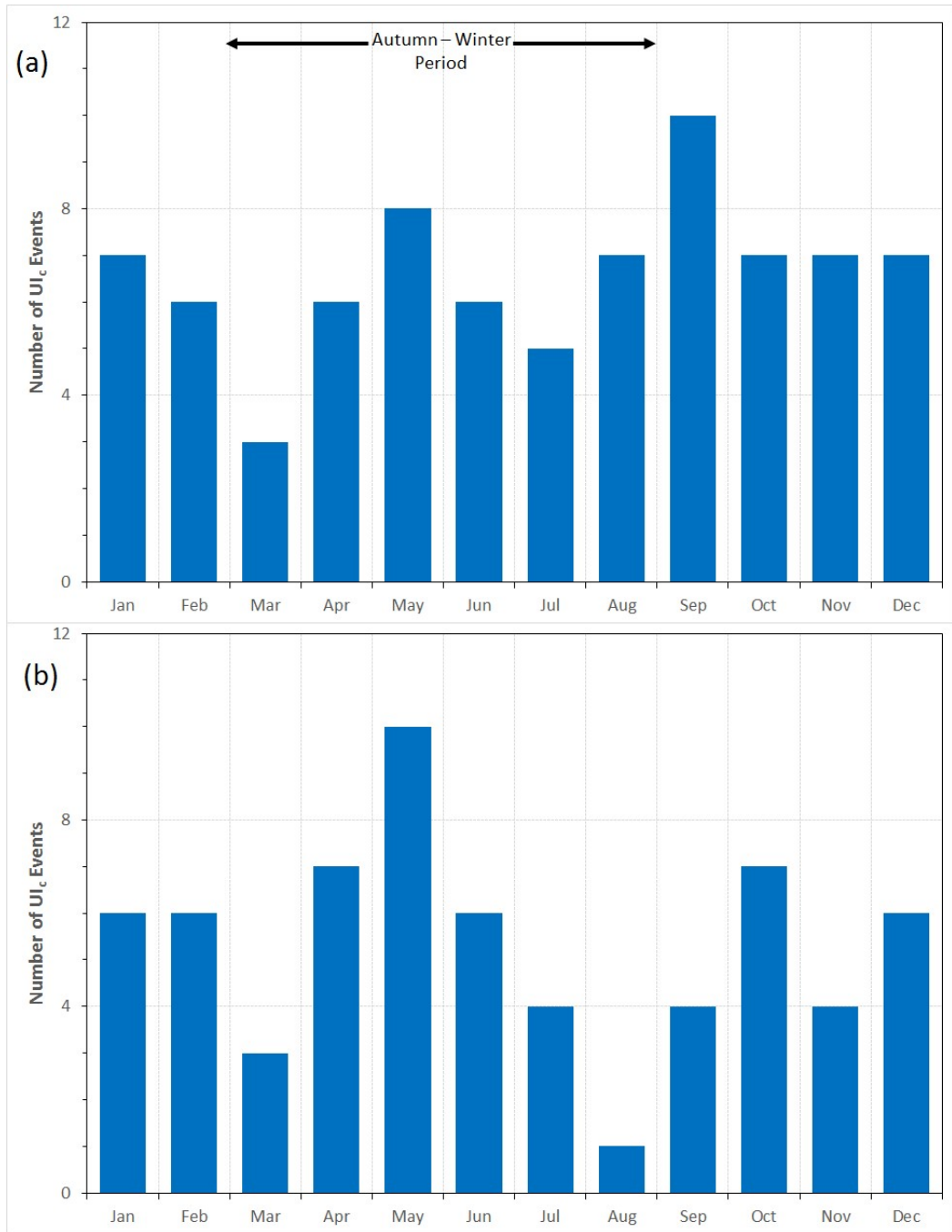

Figure 9. Cumulative number of $U I_{c}$ events at (a) $25.5^{\circ} \mathrm{S}$ and (b) $26.5^{\circ} \mathrm{S}$. 
Ocean Sci. Discuss., https://doi.org/10.5194/os-2018-142

Manuscript under review for journal Ocean Sci.

Discussion started: 9 January 2019

(C) Author(s) 2019. CC BY 4.0 License.
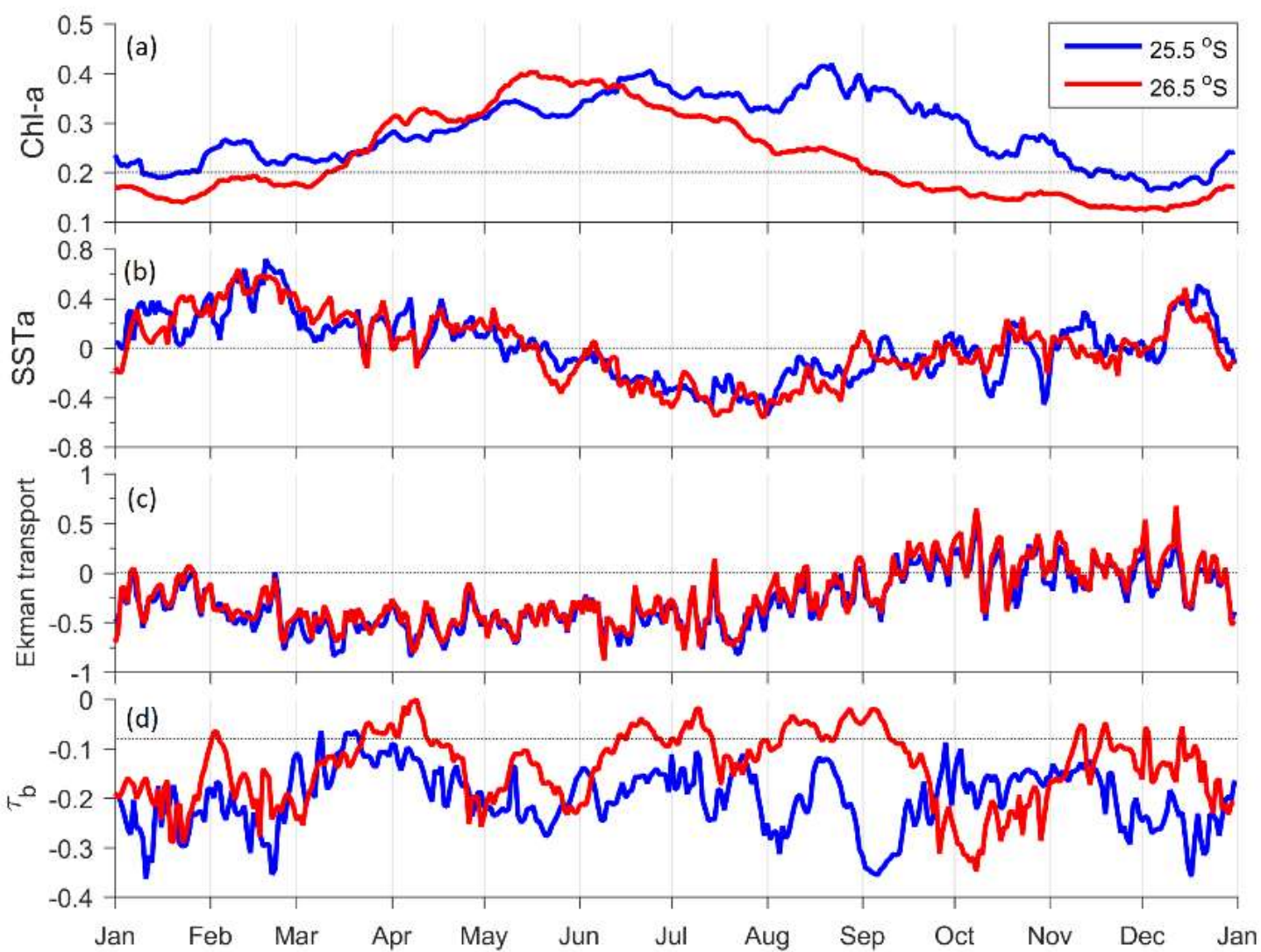

Figure 10. (a) Chl-a $\left(\mathrm{mg} \mathrm{m}^{-3}\right)$, (b) SSTa $\left({ }^{\circ} \mathrm{C}\right)$, (c) Ekman transport $\left(\mathrm{m}^{2} \mathrm{~s}^{-1}\right)$ and (d) $\tau_{b}\left(\mathrm{~N} \mathrm{~m}^{-2}\right)$ at $25.5^{\circ} \mathrm{S}$ (blue line) and $26.5^{\circ} \mathrm{S}$ (red line). The dotted line in Fig. 10a corresponds to the background value of Chl-a in SEQMCZ, while the dotted line at -0.08 $\left(\mathrm{N} \mathrm{m}^{-2}\right)$ in Fig. 10d indicates the threshold value of $\tau_{b}$ considered upwelling favourable (Everett et al., 2014). 
Ocean Sci. Discuss., https://doi.org/10.5194/os-2018-142

Manuscript under review for journal Ocean Sci.

Discussion started: 9 January 2019

(c) Author(s) 2019. CC BY 4.0 License.

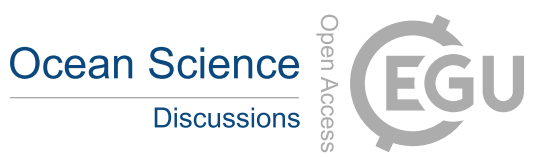

(c) (i)

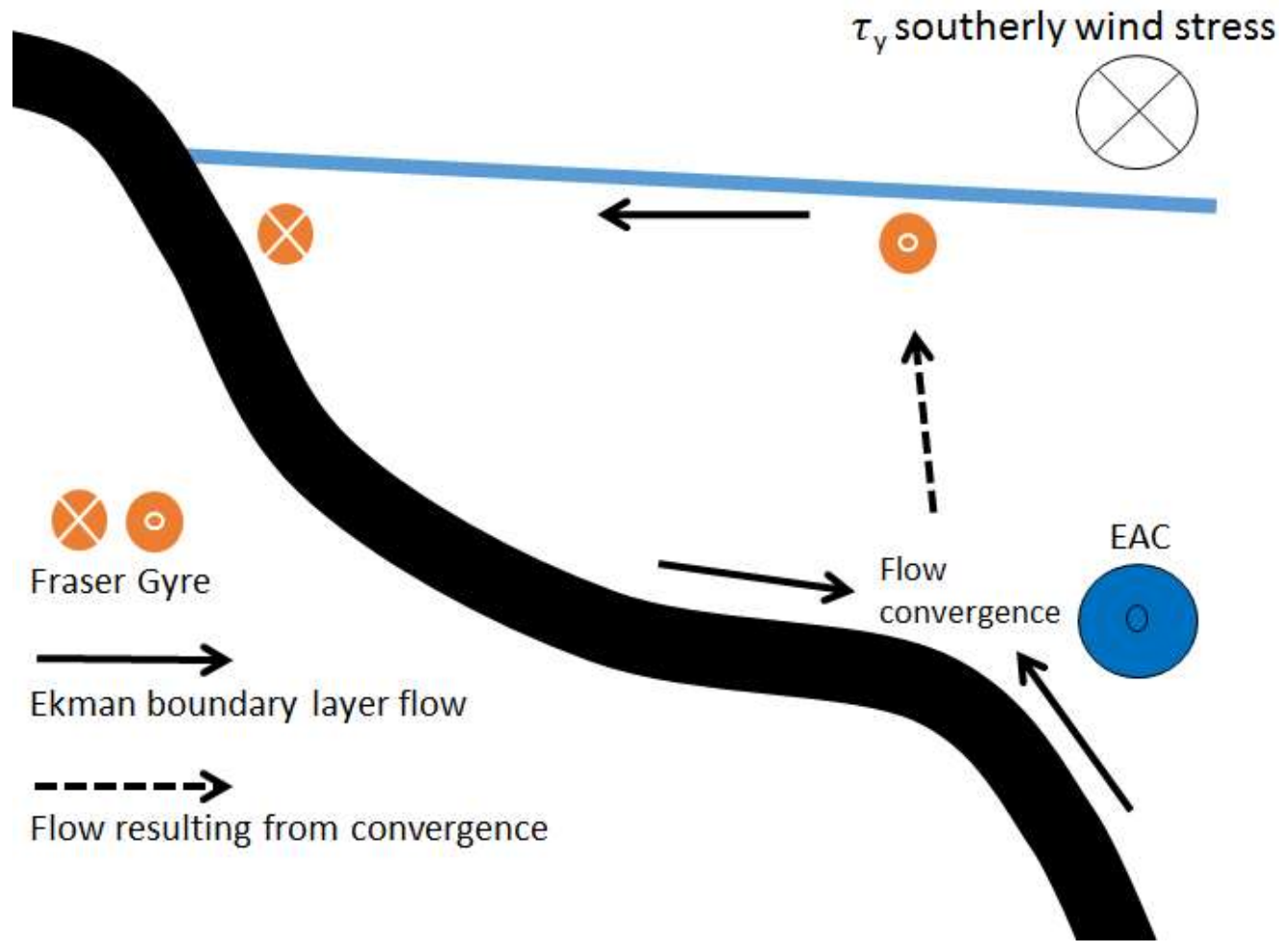

5 Figure 11. Schematic cross-shelf diagram of flow convergence that is formed under simultaneous onshore flow due to EAC's bottom stress and offshore flow due to downwelling favourable wind stress in the BBL. The flow convergence establishes a shelf break front which promotes uplift of nutrients. 

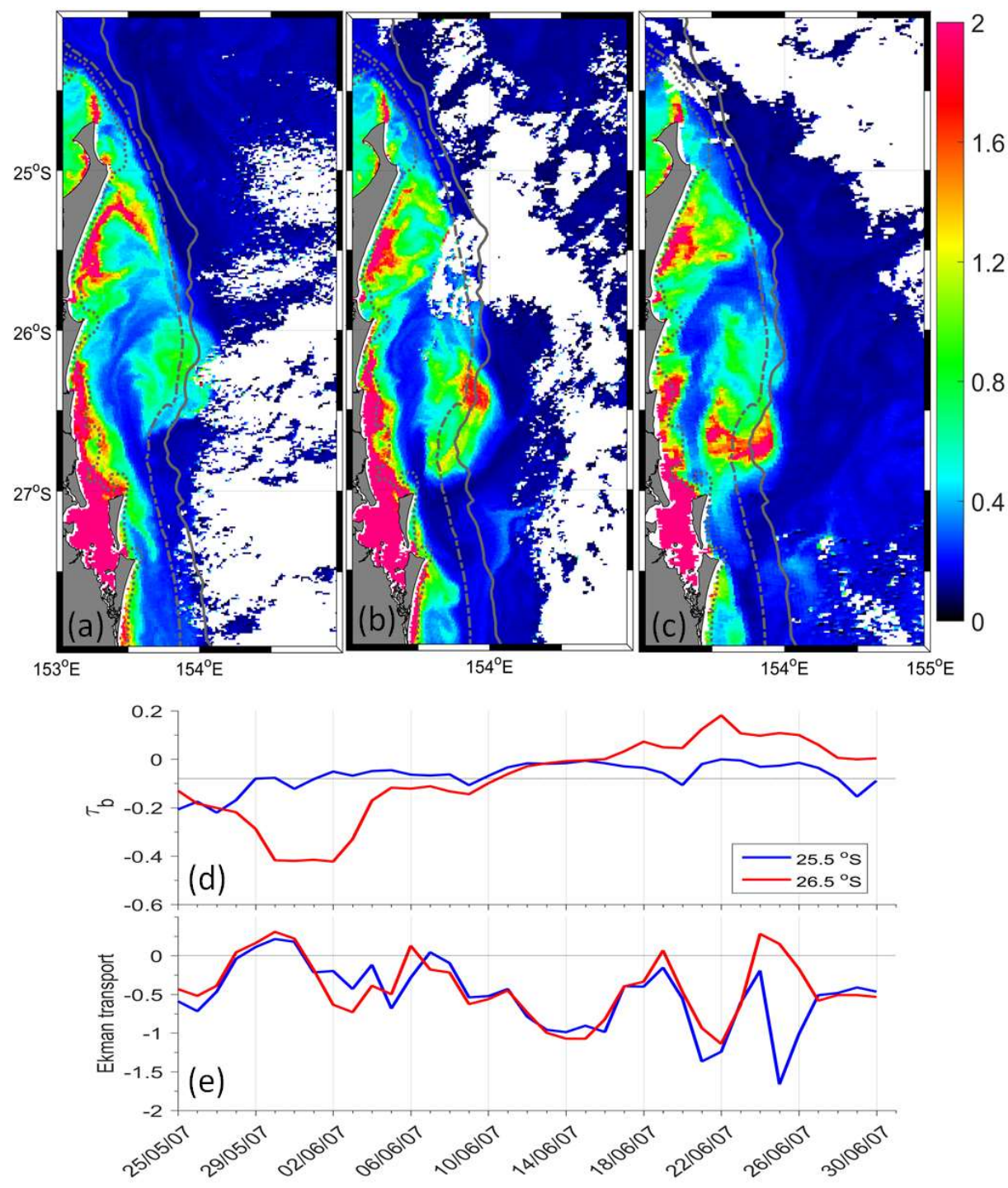

Figure 12. Chl-a $\left(\mathrm{mg} \mathrm{m}^{-3}\right)$ for June (a) 10, (b) 11, and (c) 12, 2007. Cloud coverage limits the number of days availalbe for analysis. Daily time series of (d) $\tau_{b}\left(\mathrm{~N} \mathrm{~m}^{-2}\right)$ and (e) Ekman transport $\left(\mathrm{m}^{2} \mathrm{~s}^{-1}\right)$ at $25.5^{\circ} \mathrm{S}$ (blue line) and $26.5^{\circ} \mathrm{S}$ (red line) from 25 May to 30 June 2007. The dotted black line at $-0.08\left(\mathrm{~N} \mathrm{~m}^{-2}\right)$ in Fig. $12 \mathrm{~d}$ indicates the threshold value of $\tau_{b}$ considered as 5 upwelling favourable (Everett et al., 2014). 